\title{
Transcription Factors of the bHLH Family Delineate Vertebrate Landmarks in the Nervous System of a Simple Chordate
}

\author{
Lenny J. Negrón-Piñeiro, Yushi Wu and Anna Di Gregorio * $\mathbb{C}$ \\ Department of Molecular Pathobiology, New York University College of Dentistry, 345 E 24th Street, \\ New York, NY 10010, USA; lnp260@nyu.edu (L.J.N.-P.); yw1406@nyu.edu (Y.W.) \\ * Correspondence: adg13@nyu.edu; Tel.: +1-212-998-9564; Fax: +1-212-995-4204
}

Received: 19 September 2020; Accepted: 12 October 2020; Published: 26 October 2020

\begin{abstract}
Tunicates are marine invertebrates whose tadpole-like larvae feature a highly simplified version of the chordate body plan. Similar to their distant vertebrate relatives, tunicate larvae develop a regionalized central nervous system and form distinct neural structures, which include a rostral sensory vesicle, a motor ganglion, and a caudal nerve cord. The sensory vesicle contains a photoreceptive complex and a statocyst, and based on the comparable expression patterns of evolutionarily conserved marker genes, it is believed to include proto-hypothalamic and proto-retinal territories. The evolutionarily conserved molecular fingerprints of these landmarks of the vertebrate brain consist of genes encoding for different transcription factors, and of the gene batteries that they control, and include several members of the bHLH family. Here we review the complement of bHLH genes present in the streamlined genome of the tunicate Ciona robusta and their current classification, and summarize recent studies on proneural bHLH transcription factors and their expression territories. We discuss the possible roles of bHLH genes in establishing the molecular compartmentalization of the enticing nervous system of this unassuming chordate.
\end{abstract}

Keywords: ascidian; bHLH; Ciona; CNS; epiphysis; hypophysis; hypothalamus; nervous system; notochord; sensory vesicle

\section{Introduction}

Vertebrata, Tunicata (or Urochordata), and Cephalochordata are the three clades of the phylum Chordata. Along with the other members of the subphylum Tunicata, ascidians occupy a unique evolutionary position, as they are considered the extant taxon closest to vertebrates [1]. Since the beginning of the past century, studies on ascidians have provided a valuable reference for chordate development, first by informing comparative biological studies between embryos featuring different ontogenetic strategies [2-5], and, more recently, by shedding light on the molecular mechanisms underlying a variety of developmental processes, both ancestral and derived [6-10]. These processes include formation of the notochord [11-13] neural tube closure and dorsoventral patterning [14,15], regionalization of the central nervous system (CNS) [16,17], heart development [18,19], formation of the cardiopharyngeal precursors [20-22], biosynthesis and role of thyroid hormones [23], and specialization of the digestive tract $[24,25]$. The search for compartments evolutionarily related to the anatomical structures that punctuate the vertebrate brain in invertebrate chordates stretches over several decades, and started out with comparative morphological observations and immunocytochemical studies, which have been complemented, in more recent years, by phylogenomic analyses and single-cell molecular fingerprinting. These recent investigations, several of which have been mainly focused on species belonging to the cosmopolitan genus Ciona, have revealed that the developmental programs 
of these structures rely upon a relatively streamlined molecular machinery that shares numerous homologies with its vertebrate counterparts [26-31]. Thus, studies in ascidians have been tracing back the origins of anatomical and physiological structures that emerged in these simple chordates in an uncomplicated form and have been elaborated upon by increasingly complex vertebrates.

Basic helix-loop-helix (bHLH) genes represent an ancient superfamily of transcription factors (TFs) that are widely represented in eukaryotes; they are found in plants, where they are involved in processes ranging from flower pigmentation to iron homeostasis [32,33], in fungi, where they control hyphal growth, melanin production, and virulence [21], and in all metazoan phyla analyzed thus far $[34,35]$. The evolutionary history of the bHLH superfamily has been reconstructed through molecular phylogenetic studies and comparative genomic analyses, and it is believed to have involved a diversification event during the Pre-Cambrian era, at the time when early metazoans appeared, and a subsequent expansion of the family before the split of bilaterians and cnidarians [36]. Members of the bHLH superfamily often form homodimers, and they can also heterodimerize with other bHLH proteins. These interactions influence their respective effects on transcriptional regulation, and enable them to function as either activators or repressors of gene expression in different spatial and temporal contexts [34]. It has been hypothesized that increasingly complex interactions between bHLH TFs have mediated their functional transition from ancestral regulators of cell division to coordinators of tissue differentiation [37]. Throughout metazoan phyla, members of the bHLH family of TFs regulate a variety of processes, including cell-lineage specification, cell differentiation, response to environmental stress, and maintenance of circadian rhythm, among others; in particular, bHLH TFs are critical components of the gene regulatory cascades underlying myogenesis and neurogenesis [37-40]. Consequently, their mutations and deregulation are responsible for developmental defects and diseases, and contribute to tumorigenesis and metastasis [40-42].

Here we focus on the roles of bHLH TFs in the specification and morphogenesis of nervous structures during chordate development. One reason for their widespread functions in vertebrate neurogenesis is that, during embryogenesis, bHLH TFs are expressed in crucial organizing centers of the nervous system, the zona limitans intrathalamica (ZLI) and the midbrain-hindbrain boundary (MHB, also known as isthmic organizer), where they participate in pre-patterning morphogenetic events $[43,44]$. Later on, bHLH genes participate in the differentiation of anatomo-physiological landmarks of the vertebrate CNS, such as hypophysis, hypothalamus and retinal territories, epiphysis, and habenulae, where they are involved in the differentiation of specific neuronal subtypes, hormone-producing cells, establishment of the circadian rhythm, and generation of behavioral outputs [45]. As most evolutionarily conserved bHLH genes are present in single copies in the Ciona genome, studies on their roles in the development and compartmentalization of the straightforward ascidian CNS can inform related investigations in more complex chordates, and simplify the interpretation of the phenotypes resulting from their inactivation.

\section{2. bHLH Transcription Factors and Organizing Centers in the Developing Ascidian Nervous System}

After fertilization, ascidian embryos develop into tadpole-like larvae within less than one day, and after swimming around for several hours, they rapidly metamorphose into juveniles and slowly continue to grow into adults. The simple chordate body plan of the ascidian larva contains only $\sim 2600$ cells, organized into a few main embryonic tissues, among which a notochord, located in the center of the tail, and a modest yet fascinating CNS located rostral and dorsal to it [46-48]. The notochord, the eponymous feature of the phylum, is invariantly composed of only 40 cells, and expresses homologs of Brachyury, Foxa2, and other evolutionarily conserved transcriptional regulators, resembling the more sophisticated vertebrate notochords [12,28,49-52]. In addition, genes of the homeobox family, including Otx, Hox $1, H o x 3$, and Hox 5 , are expressed in the ascidian larval CNS in a rostrocaudal pattern comparable to that seen in developing vertebrate embryos $[16,53,54]$. These comparative studies have provided evidence that the simple CNS of the ascidian larva (Figure 1A), which consists of only 177 neurons and $\sim 123$ accessory cells, exhibits a topological organization relatable to that of the three primary 
brain vesicles of vertebrates: forebrain (prosencephalon), midbrain (mesencephalon), and hindbrain (rhombencephalon) (Figure 1B). In vertebrates, the developing forebrain is subdivided into diencephalon and secondary prosencephalon. The diencephalic territories delineated as prosomeres 1, 2, and 3 (p1-p3; Figure 1B), give rise to the pretectum, thalamus, and prethalamus, respectively (Figure 1B). The secondary prosencephalon is further subdivided into the caudal and rostral hypothalamic prosomeres (hp1 and hp2, respectively; Figure 1B), which encompass the presumptive hypothalamic region, telencephalon, and optic vesicles [55-57]. The formation of these structures, in vertebrates, is orchestrated by organizers, which act as signaling centers and as local sources of fibroblast growth factor (FGF) and other instructive molecules able to induce cell divisions and early patterning events [58,59]; these organizing centers also express TFs of both the homeobox and bHLH families, among others. Interestingly, the evolutionary origins of vertebrate organizing centers have been traced back to the acorn worms, members of the phylum Hemichordata, whose non-chordate embryos contain regions that display gene expression patterns homologous to those seen in the anterior neural ridge (ANR), ZLI and MHB [60]. In ascidian embryos, a region equivalent to the ZLI is yet to be identified, even though the genomes of Halocynthia roretzi and other ascidians seem to contain bHLH genes related to Olig3, a ZLI marker [44], whose expression, however, remains to be elucidated. The existence of an ascidian MHB with organizing properties related to those observed in vertebrate embryos had been initially ruled out on the basis of the expression pattern of the MHB marker Dmbx [61]. However, subsequent studies have uncovered the dynamic expression patterns of Ciona Dmbx and Hox genes in the larval CNS, and have provided initial clues on its subtly compartmentalized structure [62]. The identification in the motor ganglion of developing Ciona tadpoles of a localized source of the Ciona ortholog of Fgf8 (Ciona Fgf8/17/18), an evolutionarily conserved mediator of the MHB organizer activity, and the reported role of Ciona Fgf8/17/18 in the specification of the neck region of the larval $\mathrm{CNS}$, are currently considered indicative that a simplified form of the MHB with organizer-like features is indeed present in the larval CNS of Ciona, and is responsible for its rostro-caudal regionalization [63]. A gene related to a bHLH TF that characterizes the MHB in Xenopus, Hes-related1 (XHR1) [43], is present in the Ciona genome (Ciona Hey, Table 1), however its expression was not detected at any of the stages analyzed by whole-mount in situ hybridization (WMISH) before metamorphosis [50].

Another organizing center required for the development of neural structures is the prechordal plate, a mesendodermal embryonic territory anterior to the notochord. In particular, the prechordal plate is required for the formation of the hypothalamus [64], and in zebrafish, it expresses a member of the Id3 bHLH subfamily [65]. A physically distinguishable structure homologous to the prechordal plate seems to be absent in ascidians. 
A

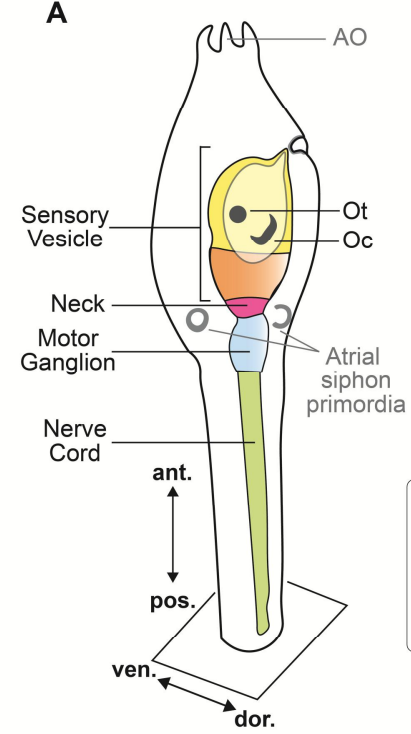

B

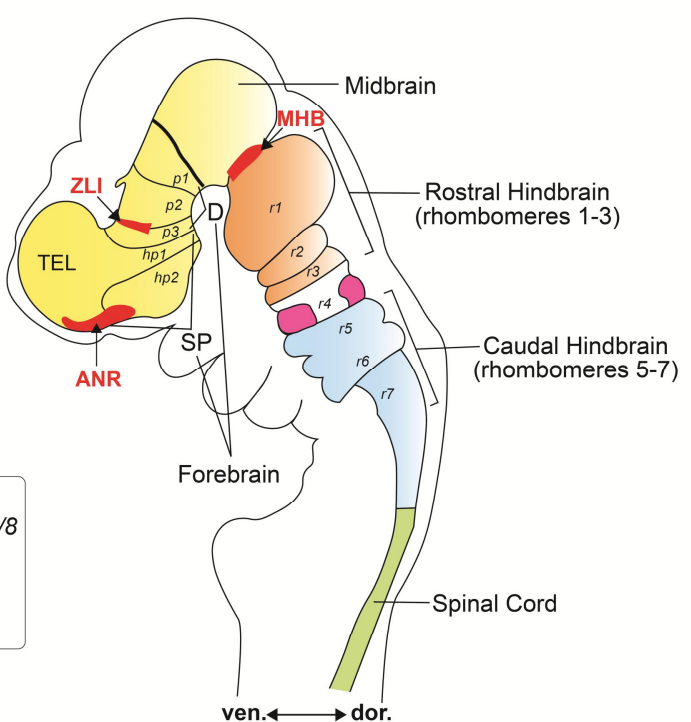

Figure 1. General organization and presumed homologous regions of the central nervous system (CNS) in ascidian larvae and vertebrate embryos. Drawings of a Ciona larva (A), $\sim 18 \mathrm{~h}$ after fertilization and a mouse embryo (B), $\sim 9$ days old (stage E9.5). The developing nervous systems of these divergent chordates exhibit a comparable anterior-posterior sequential expression of the genes Otx (yellow), Pax2/5/8 (orange), Hox1 (magenta), Hox3 (blue), and Hox5 (green). Abbreviations: ANR, anterior neural ridge; ant., anterior; $\mathrm{AO}$, adhesive organ; $\mathrm{D}$, diencephalon; dor., dorsal; hp, hypothalamic prosomere; $\mathrm{MHB}$, mid-hindbrain boundary; Oc, ocellus; Ot, otolith; p, prosomere; pos., posterior; r, rhombomere; $\mathrm{SP}$, secondary prosencephalon; TEL, telencephalon; ven., ventral; ZLI, zona limitans intrathalamica. Adapted from $[10,17,55]$.

\section{Anatomo-Physiological Vertebrate Landmarks in the Uncomplicated Nervous System of the Ascidian Larva}

In vertebrates, the forebrain develops dorsally into the telencephalon and ventrally into the diencephalon $[56,57]$. The telencephalic-derived cerebral cortex appeared in lower vertebrates and increased vastly in size and functional complexity in amniotes. Its development relies upon a delicate balance between the action of proneural bHLH TFs, such as Mouse Achaete-scute homolog 1 (Mash1), Neurogenin 1, and Neurogenin 2, which promote differentiation of cortical precursor cells, and the function of proliferation-promoting bHLH TFs of the Id and Hes subfamilies, which maintain these cells in an undifferentiated, multipotent state [66]. Differently from the cortex, the diencephalic-derived structures, hypothalamus, hypophysis, and epithalamus, are believed to have originated before the divergence of the three chordate subphyla. In the case of the hypothalamus, this hypothesis is based on the comparable regionalization of the homeobox genes Otp, Nkx2.1 and Meis between the vertebrate hypothalamic primordium, the anterior-ventral region of the sensory vesicle (SV; also known as brain vesicle) of Ciona (Figure 2A), and the anterior-most region of the CNS of the amphioxus B. lanceolatum $[29,30,55]$. The anteroventral territory of the ascidian larval CNS, which develops into a portion of the SV, contains dopamine-synthesizing cells that resemble the clusters of dopaminergic cells in the developing hypothalamus of vertebrates [29], and the presence of dopamine-synthesizing cells in the anterior-most region of the CNS is also observed in amphioxus [67]. Together, these findings support the idea that tunicates and cephalochordates inherited a proto-hypothalamus from a common chordate ancestor. Dorsal to the SV, in the ascidian larva, resides an ectoderm-derived domain that forms the stomodeum (Figure 2A,B), which is considered equivalent to a vertebrate placode [68] and gives rise to the incurrent oral siphon of the adult ascidian (Figure 2C). The stomodeum expresses the homeobox genes Pitx and Six3/6, similarly to all chordate mouth primordia examined to date $[69,70]$. 
In amphioxus, a derivative of Hatschek's left diverticulum, the ciliated pit of the preoral organ, is considered the homolog of the vertebrate adenohypophysis (anterior pituitary gland) [71]. This area expresses the evolutionarily conserved pituitary-specific marker Pit-1/POU1F1, which encodes a POU-homeodomain TF [72,73], as well as Pitx (pituitary homeobox), a paired-type homeodomain TF that acts downstream of the Cerberus/Nodal/Lefty gene cascade in the establishment of left-right asymmetry [74]. A bona fide homolog of Pit-1/POU1F1, which is required for proper pituitary development in higher vertebrates, seems to be missing from the Ciona genome [75]. Nevertheless, territories related to the vertebrate hypophysis have been identified in both the larval and the adult ascidian body plan. At the beginning of the swimming larva stage, the ectoderm-derived neurohypophyseal duct, which protrudes from the SV, makes contact with the wall of the stomodeum, and expresses Pitx, similarly to the vertebrate adenohypophysis primordium [68,75-79]. Shortly after, the lumen of the neurohypophyseal duct coalesces with that of the stomodeum, while still in contact with the lumen of the SV, at a time when the stomodeum is still plugged by the transparent tunic that covers the larval body (Figure 2A) [68]. By the late larval stages, the connection of the neurohypophyseal duct with the lumen of the SV is lost, and both the duct and the stomodeum open into the endodermally-derived pharynx [68]. At metamorphosis, the neurohypophyseal duct gives rise to the neural gland, which remains connected to the pharynx through a ciliated duct and a ciliated funnel (Figure 2C). The neural gland had originally been suggested as the adenohypophysis homolog, on the basis of the immunohystochemical properties of some of its cells [80]; however, subsequent studies in Ciona have related to the vertebrate adenohypophysis the ciliated funnel, because it expresses Pitx and derives from the oral ectoderm of the stomodeum $[68,75,81]$. Notably, TFs of the Pitx family have been shown to physically interact with ubiquitously expressed group A bHLH proteins (Table 2), and to synergize with them in the transcriptional regulation of their downstream genes during pituitary development in mice [82]. In particular, mouse Pitx1 is recruited to promoter regions by DNA-bound bHLH TFs NeuroD1 and Pan1 [82]. Together with three other proneural bHLH TFs, Neurogenin, Mash1, and Mouse Atonal homolog 3 (Math3), NeuroD1 controls hypophyseal differentiation in mice, and participates in the functional specification of hormone-secreting cells that compose the adenohypophysis [83]. In Ciona, a gene related to NeuroD, NeuroD-like (Table 1), is expressed in epidermal sensory neurons, in the anterior SV and in the motor ganglion [84]; however, its possible overlap with Ciona genes related to Achaete-scute and Atonal has not been ascertained. 
A

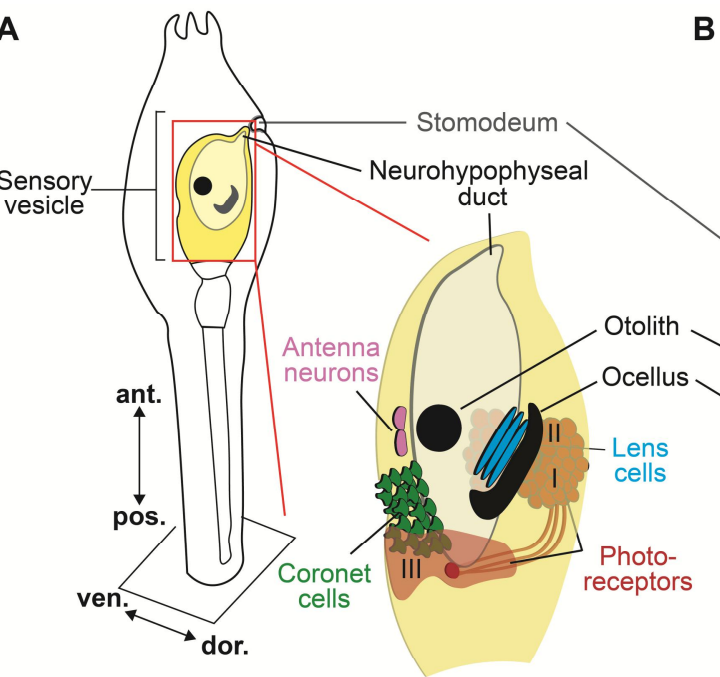

B

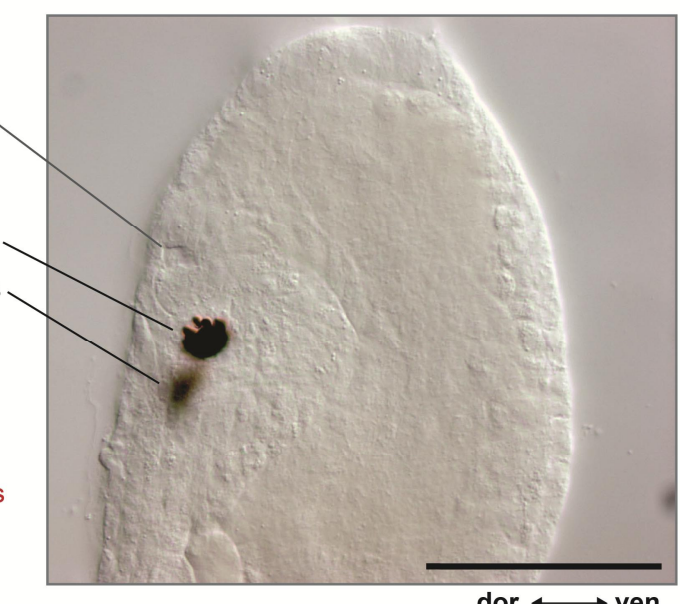

C

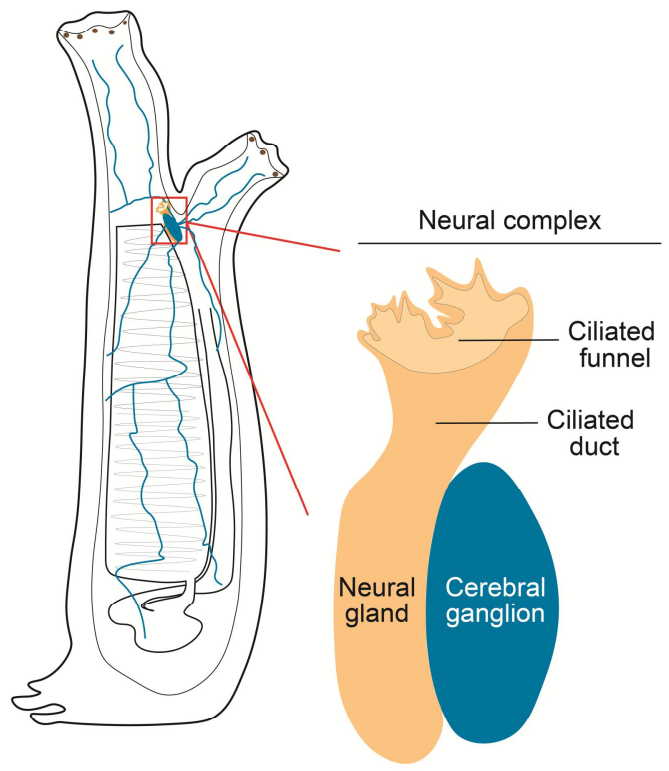

Figure 2. Larval sensory vesicle and adult neural complex of Ciona. (A) Schematic view of the sensory vesicle, the 'brain' of the ascidian larva, its sensory organs, and the primordia of the hypophysis and stomodeum. On the right side of the sensory vesicle reside the pigmented ocellus and the associated lens cells and photoreceptors (group I and II), whereas the left side contains the otolith, antenna neurons, coronet cells, and photoreceptor cells (group III). (B) Microphotograph of the trunk of a Ciona larva, showing the developing stomodeum, the otolith, and the ocellus. Scale bar: $25 \mu \mathrm{m}$. (C) Schematic view of the sessile filter-feeder adult, highlighting the neural complex, located between the two siphons, and its components, the cerebral ganglion and the neural gland. Nerve fibers from the neural complex (blue) innervate multiple organs and tissues. Adapted from $[48,85,86]$.

Another anatomical point of reference of the vertebrate CNS, the epithalamus, which consists of the epiphysis (aka pineal gland, or pineal eye) and the two habenulae, relies on bHLH TFs for its formation $[87,88]$. Structures related to the vertebrate epithalamus have been identified in the simple nervous systems of cephalochordates and tunicates. In amphioxus, the lamellar body, a ciliary photoreceptor, is considered a presumptive epiphysis [89,90]. Even though ascidians lack an organized epiphysis, the Ciona larval CNS expresses Noto, a homeodomain TF that in zebrafish controls expression of two other bHLH TFs required for epiphyseal neurogenesis, Neurogenin 1 (ngn1) and Achaete-scute homolog 1a (ash1a) [91]. Ciona Noto is expressed in the posterior notochord and in the SV of tailbud 
embryos, where it is detected anteriorly to the otolith and the ocellus, and in between these sensory organs, where it is expressed at lower levels [92]. The single-copy Ciona Neurogenin (Ci-Neurog) is expressed in several small areas of the SV (see below), and one of the Achaete-scute-like genes (Table 1), is expressed in a small region of the anterior-ventral SV [50]. In addition, it has been proposed that the ocellus might represent a structure homologous to the epiphysis [93], which is also known as median eye, rather than to the lateral eyes of vertebrates, based on its shadow response, which in larvae of Xenopus is controlled by the epiphysis $[93,94]$. In vertebrates, the epiphysis and the suprachiasmatic nucleus control the circadian rhythm of the entire organism and its ability to adjust its metabolism to environmental changes, and bHLH-PAS type TFs expressed in these structures are in large part responsible for these functions [95]. Even though the C. robusta genome lacks clear orthologs of the bHLH circadian regulators, Clock, Period, Dec1 and Bmal1, several genes show a nearly circadian rhythmic expression [96].

\section{Cellular and Molecular Topography of the Ciona Larval Nervous System}

After hatching from the protective chorion in which they develop for approximately $18 \mathrm{~h}$, the lecithotrophic ascidian larvae begin to swim around, in search of a submerged substrate where they will settle, metamorphose, and start their adult life as sessile filter-feeders [10]. About $1.5 \mathrm{~h}$ after hatching, the larvae begin to exhibit intermittent tail flicks and spontaneous swimming, and develop a shadow response, being stimulated to swim by sudden reductions in light intensity [97]. In addition, they exhibit negative gravitaxis, and swim towards the surface of the water, while later on they start swimming away from the surface of the water in search of a dimly lit substrate, presumably hidden from possible predators, to which they will attach and spend the rest of their life [98] this latter behavior is originated by a negative phototactic response [99]. In addition to gravitaxis and phototaxis, ascidian larvae are capable of chemotaxis and mechanosensory responses (thigmotaxis) and can enter a state of sensory arousal [98]. Remarkably, swimming Ciona larvae can be sensitized through recurring variations in luminous stimuli, and can even show habituation and short-term retention of their responses $[100,101]$. The larval CNS is responsible for coordinating sensory processing, and for orchestrating the transition from the stereotypic free-swimming behavior of the hatched larvae to their commitment to find the substrate that will serve as their definitive home [102]. The ascidian larval CNS comprises four main structures; the hollow SV and the motor ganglion, also known as visceral ganglion, which are connected by a narrow neck, reside within the trunk (Figure 1A), while the tail contains the nerve cord (NC), which is composed by non-nervous accessory cells, known as 'ependymal' cells, and by the axons of neurons located in the motor ganglion [48]. The cholinergic motor neurons of this ganglion require for their specification a bHLH TF, the single-copy Ciona Ebf, which is also sufficient to elicit cholinergic characteristics when ectopically expressed in non-cholinergic neurons (Table 1) [103].

Together, these compartments contain approximately 330 cells, among which are 177 neurons that fall into several different subtypes based on their morphology and connectivity $[27,48]$. The simple compartments of the larval CNS of Ciona display anterior-to-posterior regionalized expression of the homeobox genes Otx, Pax2/5/8, and Hox 1 comparable to those observed in the vertebrate forebrain, midbrain, and hindbrain (Figure 1) $[16,27,31,48,97,104]$. In addition to the CNS neurons, the ascidian larva contains two pairs of bipolar tail neurons, which are considered homologous to the neurons of the dorsal root ganglia of vertebrates and whose bodies are located between the nerve cord and the tail epidermis [105], and several peripheral sensory neurons, scattered throughout the epidermis and organized into small groups in the papillae of the adhesive organ (Figure 1A) [106,107].

Similar to the brain of vertebrates, cell types and structures in the larval SV of ascidians display a distinct left/right side asymmetry, namely a right-sided ocellus and left-sided coronet cells (Figure 2A), which suggests that asymmetric CNS features may have appeared early during chordate evolution [48]. The larval SV is considered the most complex structure of the ascidian CNS, and is composed of two conspicuous melanin-pigmented sensory systems, the otolith (also called statocyst) and the ocellus (Figure 2A), which respond to Earth's gravitational field and light, respectively [17,48,102,108-110]. 
The otolith is a unicellular organ. This nearly spherical cell contains a large intracellular pigmented granule that protrudes into the SV cavity and is anchored to the ventral wall of the SV by a L-shaped foot $[111,112]$. The otolith is associated to a pair of ciliated cells and afferent glutamatergic antenna sensory neurons connected to relay neurons that project, across the neck, to the motor ganglion; together, these structures constitute the fairly simple gravitactic circuit of the ascidian larva [102]. The ocellus is a multicellular organ constituted by three components: one cup-shaped pigment cell, three lens cells, and about 30 photoreceptor cells, which are divided into three different groups based on their morphology and their location within the SV [113]. The photoreceptors of groups I and II are associated to the pigment cell located at the right dorsal side of the SV, while those of group III are located ventro-medially and constitute the non-pigmented ocellus, whose function is yet to be ascertained [112,114,115]. The photoreceptor cells also express a vertebrate-type opsin, Ci-opsin1, and Ci-arrestin; another opsin, Ci-opsin3, is expressed throughout the entire SV [93,101,114]. Both function and formation of the ocellus depend upon the evolutionarily conserved homeodomain TF Retinal homeobox ( $\mathrm{Rx}$ ), and its inactivation via morpholino oligonucleotide (MO) microinjection impairs both formation and function of this structure $[116,117]$. On the other hand, a bHLH TF, Mitf, has been shown to be essential for the formation of melanin-synthesizing pigment cells in vertebrates [118], and in the ascidian $H$. roretzi the ectopic expression of this gene is sufficient to induce the expression of genes necessary for melanogenesis [119]. Of note, the pigment cells of the ascidian $\mathrm{SV}$ are considered homologous to the vertebrate melanocytes, which are neural crest derivatives and thus represent an additional attribute shared by ascidians and vertebrates [120]. Interestingly, repression of the melanogenetic activity of Mitf in the ocellus precursors by FoxD is responsible for the reduced pigmentation of this photoreceptor structure [120]; a similar molecular mechanism is employed in zebrafish embryos to suppress Mitf-dependent melanogenesis in the neural-crest derived light-reflecting iridophores [121].

Another bHLH TF involved in neural crest cells migration, localization, and differentiation in vertebrate embryos is Twist, which is required, in particular, for the specification of both cephalic and cardiac neural crest cells [122,123]. Interestingly, the Ciona genome contains three copies of 'Twist-like' genes, likely resulting from a lineage-specific duplication, and they are all expressed in the mesenchyme, the pluripotent group of cells that remain relatively undifferentiated during embryonic development and after metamorphosis give rise to several adult structures, including body wall muscle, blood cells, and cells of the cellulose-based tunic [10,50]. Reportedly, the bHLH domains of Twist-r.a and Twist-r.b are identical, while their C-terminal regions are divergent [124]. Of these three Twist-like genes, Twist-r.b (Table 1) is the closest to human TWIST1, and when ectopically expressed in the progenitors of the pigment cells (a9.49 lineage) [125] is able to reprogram these cells, which are normally stationary, into migrating neural-crest-like cells [120].

Within the presumed hypothalamic region of the SV, described above, resides a group of cells that express tyrosine hydroxylase (TH), the enzyme involved in the rate-limiting step of the biosynthesis of dopamine and other catecholamines. These TH-expressing cells include different cell types, among which a subpopulation of coronet cells and at least one neuronal subtype [29]. The coronet cells, which send bulbous protrusions into the cavity of the SV, are located anteriorly to the group III photoreceptors, on the left side of the ventral wall of the SV (Figure 2A) [48]. The role of coronet cells in ascidians is still debated; nonetheless, based on the expression of TFs and other molecular fingerprints, such as components of the catecholamines synthesis pathway, they are considered related to the amacrine dopaminergic cells of the vertebrate retina $[29,109]$. Through functional studies, the Ciona coronet cells were revealed capable of accumulating serotonin [126]. Together with the reported expression in the SV of other markers of the hypothalamus and retina of vertebrates, such as Six3/6, $R x$, Meis, Pax6, and visual cycle proteins, these findings support the idea that the ascidian CNS may have inherited a proto-retinal territory from a chordate ancestor $[126,127]$. The posterior-most region of the SV contains in its left dorsal side one large interneuron, the eminens cell, which projects directly to the proximal tail, and in its ventral side two interneurons, whose projections arch dorsally before 
extending towards the tail (large ventroposterior sensory interneurons [106,112]. All these neurons, as well as the recently identified additional eminens neurons, are considered GABAergic [97,112,128]. Single-cell transcriptional profiling has determined that eminens neurons express several bHLH genes, including Ebf, Bhlh-tun2, Max, and Neurog [27] (Table 1).

\section{5. bHLH Transcription Factors in the Nervous System of Adult Ascidians}

At metamorphosis, ascidian larvae lose some of the defining features of the chordate body plan, however they develop another chordate staple, the pharyngeal slits, in addition to a functional digestive tract, a tubular heart, and a primitive thyroid, the endostyle [129,130]. Along with the notochord and the muscles flanking it, the larval nerve cord disappears during tail retraction. However, while most of the larval neurons are lost, the non-neural ependymal cells act as pluripotent stem cells and give rise to most of the neurons of the adult CNS [131]. A small number of neurons derive from the delamination of the neurohypophyseal duct [68], and localize to the anterior tip of the ciliated funnel (Figure 2C) [131]. The adult nervous system consists of the neural gland, which derives from the neurohypophyseal duct, and the cerebral ganglion, which is mainly formed through the transdifferentiation of the larval ependymal cells [131]. Despite their transition from motile to sessile life forms, and the massive remodeling of their nervous system, which includes the loss of their photoreceptors, adult ascidians are still capable of responding to light stimuli. In particular, variable light stimuli can induce adult ascidians to contract their siphons and to spawn their gametes [132]. These responses have been attributed to the pigmented spots around the openings of the siphons, which are tentatively regarded as photoreceptors (Figure 2C) [133], and to the presence of retinal proteins and light-sensitive neurons in the cerebral ganglion [134,135] (Figure 2C). WMISH studies have revealed the nearly ubiquitous expression of Hif, Myc, and ARNT in the neural gland, and in numerous other structures of Ciona juveniles (Table 1) [136]. Instead, Hes.b exhibits a more localized expression in young adults, being expressed in the body wall muscle and in the stigmatal cells of the branchial sac, the site of a stem cell niche whose descendants contribute to the regeneration of the oral siphon [137]. Expression of AHR in Ciona juveniles was not detectable by WMISH, which suggests that this gene may not be expressed at this stage [136]. The expression patterns and the roles of the other bHLH genes in young adults remain to be characterized.

\section{The bHLH Family of Transcription Factors in Ciona}

Ciona robusta (previously C. intestinalis type A) [138] features one of the most compact chordate genomes $(\sim 120 \mathrm{Mb})$, estimated to contain 14,072 genes [139,140], of which nearly 400 encode for TFs [50]. Several large-scale studies using WMISH analysis and MO-mediated gene knockdowns have elucidated the expression patterns and the functions of numerous genes, and have outlined their roles in the development of the embryonic tissues of Ciona [50,136,141-145]. In addition, a large-scale study has identified the consensus binding sites for several Ciona TFs [146].

The number of genes encoding for bHLH proteins varies across species; the Drosophila genome contains 59 bHLH genes, while in humans the number of these genes has expanded to approximately 125 [36,147]. Of the 46 bHLH genes identified in the genome of Ciona robusta, 41 have been analyzed using WMISH and/or single-cell transcriptomic analyses; among these, at least 21 are expressed within the SV, the ascidian 'brain', during the tailbud stages (Table 1) [50], and are the main subject of this discussion (Figure 3). The bHLH domain consists of $\sim 60$ amino acids, organized into a cluster of conserved basic amino acid residues adjacent to two amphipathic $\alpha$-helices, separated by a non-helical loop [148-150]. The bHLH domain mediates both the binding to DNA and the formation of either homodimers or heterodimers between different family members $[148,149,151]$. bHLH TFs belonging to different groups recognize different hexanucleotide sequences, referred to as E-box sequences (generic consensus sequence: CANNTG), and depending on the dimerization complexes that they form, they can act as either activators or repressors of transcription [148,152]. Initially, bHLH TFs were classified into different groups based on a combination of parameters, including their tissue 
distribution, affinity to DNA, and dimerization potential [150]. Later on, another classification method, based on phylogenetic relationships, presence of additional structural domains, and E-box binding affinity, has categorized bHLH TFs into six major groups (Table 2A-F) $[148,150,151]$. Hence, the 46 C. robusta genes that encode for bona fide bHLH TFs have been assigned to these six different groups (Table 2) [147], as discussed in detail hereinafter.

It is noteworthy that despite the compact size and relative simplicity of the Ciona genome, several lineage-specific duplications have been detected in the case of different families of transcriptional regulators, including the homeobox [153,154], the T-box [155], and the bHLH family as well. The genome of Ciona robusta contains three copies of Twist genes, but only one myogenic bHLH gene, Ci-Mrf, related to the four vertebrate myogenic factors, MyoD1, Myf5, MRF4, and myogenin [156], in addition to eliciting muscle differentiation, Ciona Mrf is able to suppress both notochord and endoderm development when ectopically expressed in these tissues [157]. In contrast, the ancestral Mrf gene has independently expanded in the amphioxus genome [158]. Both C. savignyi and C. robusta possess a single copy of Mesp, which has been shown to be necessary for the specification of the tubular heart that forms shortly after metamorphosis [159-161], as opposed to Mesp1 and Mesp2 genes found in vertebrates, which are responsible for heart progenitors specification and somitogenesis, respectively, and are often functionally redundant [162].

\subsection{Group A}

Group A bHLH genes are characterized by their ability to recognize and bind the E-box consensus sequences CAGCTG or CACCTG, either as homo- or heterodimers [148,150]. At least six Ciona group A bHLH TFs are expressed at the tailbud stage within the SV territory, namely Ptf1a, Ptf1a-r, Tcf3, Atoh8, Ascl.c, and Neurogenin (Figure 3B).
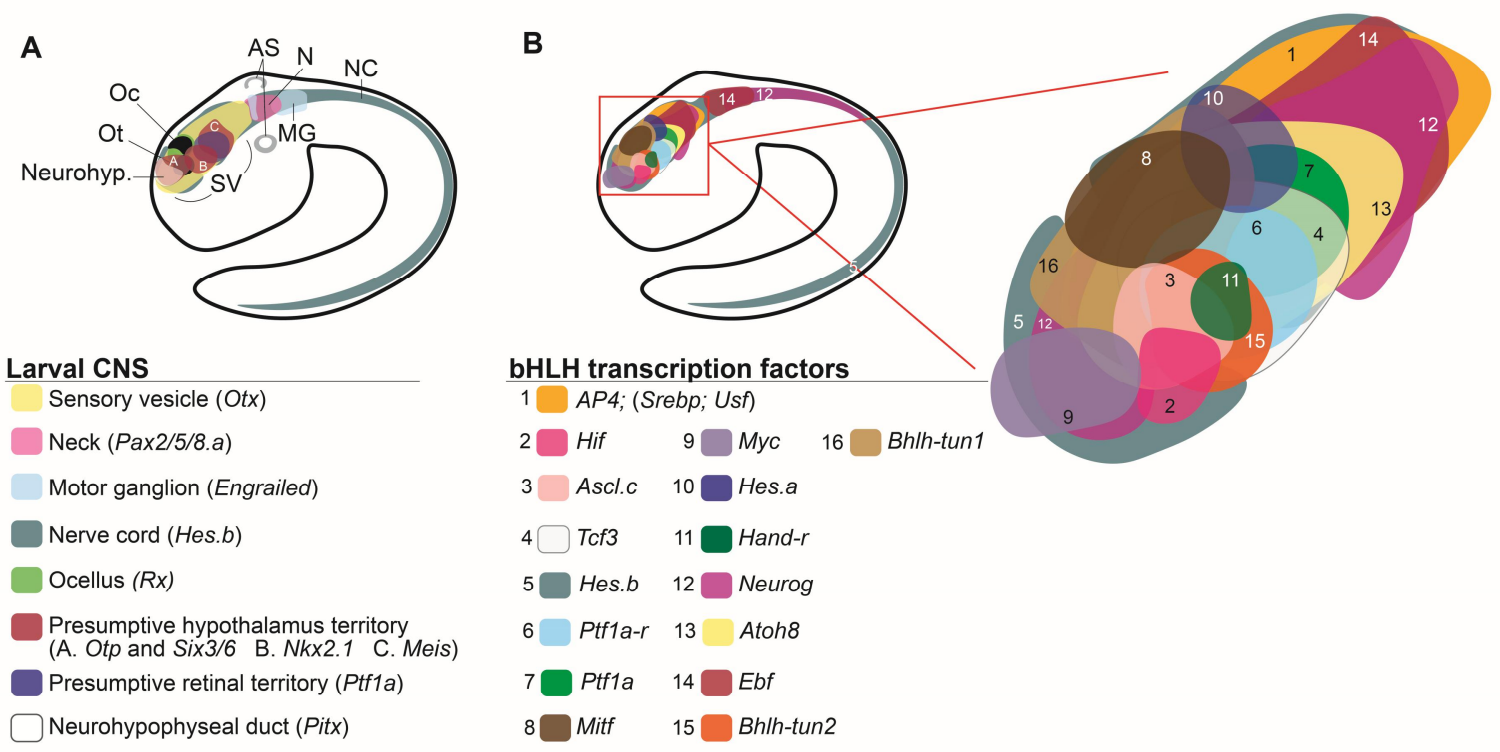

Figure 3. The panoply of bHLH genes expressed in the modest CNS of the Ciona larva. (A) The four main subdivisions of the larval CNS, as delineated by the expression patterns of Otx (sensory vesicle) Pax2/5/8.a (neck), Engrailed (motor ganglion), and Hes.b (expressed in all previous subdivisions, and in the nerve cord). The region of the sensory vesicle posited to represent a proto-hypothalamus-retinal territory is delineated by the expression of Otp, Six3/6, Nkx2.1, Meis, and Ptf1a. The territory that gives rise to the photoreceptors associated to the ocellus is marked by the expression of $R x$, and the neurohypophyseal primordium is labeled by the expression of Pitx. Adapted from [62]. (B) The palette of bHLH genes expressed in the Ciona SV and the complex tapestry that they delineate within this simple chordate brain. Each electronic brushstroke symbolizes the approximate expression pattern of a different bHLH gene, reconstructed from published WMISH expression analysis at mid/late-tailbud 
stage, according to the color/number code below this panel. The expression territories of Tcf3, Id.b and Mnt- $r$ have not been included because the results of their respective WMISH were unclear. Adapted from: $[29,50,84,108,120,145,163-166]$. Abbreviations: AS, atrial siphon primordium; MG, motor ganglion; N, neck; NC, nerve cord; Neurohyp., neurohypophyseal primordium; Oc, ocellus; Ot, otolith; SV, sensory vesicle.

In vertebrates, Ptf1a, HEB, and E2A, the counterparts of Ptf1a, Ptf1a-r, and Tcf3, associate to form the heterotrimeric PTF1 complex. Ptf1a and HEB constitute the two DNA-binding subunits of the PTF1 complex, while E2A is required to import the complex into the nucleus [167]. Potential components of the PTF1 complex have been identified in the genome of C. robusta. Ci-Ptf1a (Ciona pancreas-associated transcription factor 1a) is exclusively expressed in the TH-expressing coronet cells of the SV at the tailbud and larval stages $[126,165]$. The territory of expression of Ci-Ptf1a-r (Ciona pancreas associated transcription factor 1a-related) at the mid/late tailbud stages is nearly overlapping with that of Ci-Ptf1a (Figure 3B). The precise territory of expression of Ci-Tcf3 (Ciona transcription factor 3) is not very clear, however it seems that this gene might be expressed at low levels throughout the SV, and more intensely in the territory that overlaps with the expression domain shared by Ci-Ptf1a and Ci-Ptf1a-r [50], which would suggest that a complex homologous to the vertebrate PTF1 complex might exist in Ciona (Figure 3B).

MO-mediated loss of function of Ci-Ptf1a obliterated coronet cells development, while its overexpression resulted in the formation of supernumerary coronet cells, indicating that Ci-Ptf1a is indispensable for the specification of this cell type [165]. In vertebrates, Ptf1a is required for the specification and differentiation of both amacrine and horizontal cells of the retina, and, in particular, of the sub-population that synthesizes the neurotransmitter $\gamma$ aminobutyric acid (GABA) $[168,169]$; in addition, Ptf1a is required for the development of GABAergic neurons in the dorsal horns of the spinal cord and for the differentiation of pancreatic progenitors $[170,171]$.

Ciona Neurog is another bHLH TF of group A expressed within the SV at the tailbud stages [50]. The expression of Neurog initiates at the gastrula stage in precursors of the lateral ependymal cells of the nerve cord, and persists throughout embryonic development in the anterior nerve cord and in several areas of the SV [50]. Within the SV, Neurog is expressed in the territory that gives rise to several interneuron subtypes, including bipolar interneurons, coronet-associated ciliated SV interneurons, ciliated brain vesicle interneurons, and others [50,86]. In the tail, Neurog is necessary and sufficient for the specification, delamination, migration, and differentiation of the bipolar tail neurons (BTNs) [105]. BTNs are proposed as homologs of vertebrate dorsal root ganglia (DRG) neurons, based on the expression of Neurog in these cell types, their morphogenesis, their developmental origin from neural crest-like cells, and their role in relaying peripheral sensory information to the CNS [108]. The overexpression of Neurog resulted in the formation of supernumerary BTNs that recapitulated the stereotyped behaviors of neural crest cells [105]. A transcriptome profiling of BTNs determined that, in these cells, Neurog influences the expression of 698 genes out of 11,777 analyzed. Of the 76 Neurog-downstream targets that were further analyzed by in situ hybridization, 49 were confirmed to be expressed in BTNs, and 24 of them were found to be expressed within the SV as well [108]. Among them is Bhlh-tun2 (Table 1). MO-mediated knockdown of Neurog resulted in the down-regulation of the zinc-finger protein Myt1, of Fgf8/17/18, and of Delta-like in the trunk lateral cells, which are the precursors of blood cells, longitudinal muscle, and oral siphon muscle of the adult [108]. In addition, the knockdown of Neurog resulted in the slight up-regulation of Neurog transcripts, which might indicate a negative autoregulatory feedback [164]. In vertebrates, the single-copy Neurog found in Ciona and non-chordate invertebrates has expanded into a gene family that includes Neurog 1, 2 and 3; all these genes are important regulators of the subtype-specification and differentiation of neurons located in various regions of both the central and peripheral nervous system [172,173]. During mouse neurogenesis, around the E12 stage, Neurog 1 and 2 are expressed in the ventricular zone of the ventral midbrain, the territory where mesencephalic dopaminergic neurons develop [174,175], while Neurog 3 expression is seen in neurons adjacent to the floorplate [173]. 
Loss-of-function experiments revealed that Neurog 2 affects the generation of dopaminergic neurons in the ventricular and intermediate zone of the ventral midbrain without affecting other types of neurons, demonstrating that Neurog 2 is an essential regulator required for the differentiation of neural progenitors (Sox2 ${ }^{+}$cells) into dopaminergic neuron precursors $[174,175]$. The fact that Neurog is expressed in the dopaminergic neurons of the Ciona nervous system suggests that its function in the specification of these neurons is conserved across divergent chordates.

Three additional group A bHLH genes with expression in the SV are Atonal bHLH transcription factor 8 (Atoh8), Achaete-scute family bHLH transcription factor.c (Ascl.c), and Heart and neural crest derivatives expressed-related (Hand-r). Atoh8 is broadly expressed in the central SV territory and overlaps in part with the ventral expression territory of Ascl.c and Hand-r (Figure 3B). The expression territories of Ascl.c and Hand-r also intersect, and partly overlap with those of Ptf1a, Ptf1a-r, and Tcf3, the presumptive Ciona PTF1 complex (Figure 3B) [147,165]. Of the other two Ascl genes in C. robusta, Ascl. $a$ is expressed in epidermis and presumptive palps [50]; Ascl.b is activated in the dorsal ectoderm by the homeodomain TF Msx, and together with Tox, a high-mobility group TF, controls the differentiation of epidermal sensory neurons [163].

\subsection{Group B}

The genome of C. robusta contains 10 genes encoding for bHLH TFs of the phylogenetic group B, which recognize a different set of E-box sites (CACGTG or CATGTTG) [150,176] (Table 2). Genes of this group encode for the most prevalent type of bHLH proteins in animals [148,177]. A number of TFs within this group contain a leucine-zipper dimerization domain contiguous to the HLH domain, and can act as either transcriptional activators or repressors $[148,150,176]$. WMISH expression analysis revealed that seven bHLH genes of group $B$ are expressed in the SV at the tailbud stages, namely AP4, Mad, Mitf, Mnt-r, Myc, SREBP, and Usf (Table 1). Most of them exhibit a broad expression in this territory, whereas Mitf is localized to the pigmented cells of the ocellus and otolith (Figure 3B) [178]. The expression of Myc coincides with that of Pitx in the neurohypophyseal duct, and it extends to the anterior-most part of the SV (Figure 3A,B).

Mad was previously described as a notochord gene in a screen aimed at the identification of transcriptional targets of the T-box TF Brachyury, and was originally named Noto7 [179]. In addition to being expressed in the notochord, this gene is expressed in SV, tail epidermis, and muscle [50]. Its expression in the notochord, and its dependence upon Brachyury, suggest that Mad might be part of the Ciona notochord gene regulatory network, similarly to Bhlh-tun1 $[12,166]$ and possibly Ci-ARNT, another Brachyury-downstream bHLH gene, which is reportedly expressed in the notochord before metamorphosis and is detected in several tissues of juveniles, including the neural complex [136,180] (Table 1). Expression of Mad in the developing CNS seems dynamic, as its transcripts are initially detected throughout the periphery of the SV, while the hybridization signal in larvae is less clear and seems more concentrated to the anteriormost region of the SV [50]. This latter pattern seems confirmed by the enhancer activity of a genomic region upstream of the Mad transcription start site (our unpublished results).

No expression data are available for Figla-r. In vertebrates, Figla (Folliculogenesis-specific bHLH transcription factor) is one of the transcription factors exclusively expressed in germ cells, and is active during early folliculogenesis [181,182].

\subsection{Group C}

The bHLH TFs of Group C contain, in addition to the bHLH domain, the Period-ARNTSingle-minded (PAS) domain, which can be present in either single or multiple copies $[147,150]$. The PAS domain consists of $\sim 260-310$ amino acids and is required for dimerization between PAS-containing proteins, for interactions with non-PAS proteins, and for binding to small molecules, such as dioxin $[183,184]$. This domain also functions as a signaling sensor that monitors changes in light, oxygen, redox potential, and overall energy levels in the cell $[150,185]$. In the genome of C. robusta 
there are five genes that encode for bHLH-PAS proteins, namely Hif, ARNT, Sim, AHR, and Trh, all with respective counterparts in vertebrates $[50,147]$ (Table 2).

Ciona Hif (Ciona hypoxia inducible factor, counterpart of vertebrate Hif1 $\alpha$ ) encodes a bHLH-PAS TF that is ubiquitously expressed throughout early Ciona embryogenesis, and later, during the tailbud stages, becomes restricted to mesenchyme and nervous tissue within the trunk [30]. Moret et al. [30] also demonstrated that in Ciona tailbuds Hif is expressed in the anterior and ventromedian neural tube, in a small group of cells nestled between the expression territories of Otp and Meis (Figure 3B). In vertebrates, ARNT (Aryl Hydrocarbon Receptor Nuclear Translocator) and Sim (Single-minded) are known to be interacting partners of Hif $1 \alpha$, and together, these TFs are required for the differentiation of hypothalamic neuroendocrine cell types of the paraventricular and supraoptic nuclei $[30,186]$. In Ciona, the expression of ARNT in the SV is unclear, and that of Sim remains to be determined, hence it is not possible to determine whether Hif expression is sufficient for the specification and differentiation of any specialized cell types within the SV.

\subsection{Group D}

The bHLH TFs of the phylogenetic group D lack the basic domain preceding the HLH domain and cannot bind to DNA. Still, they are able to form heterodimers with other bHLH TFs and to antagonize their transcriptional activity $[147,148]$. C. robusta contains only two bHLH genes of group D: Inhibitor of DNA binding a (Id.a) and Inhibitor of DNA binding b (Id.b). Id.a and Id.b are both located on chromosome 7 in opposite orientations and are separated by $\sim 9 \mathrm{~kb}$. This interval is occupied by three unrelated gene models, which could be indicative of a chromosomal rearrangement [140]. Single-cell transcriptomic profiling suggests that both genes are expressed in the wall of the SV [31] (Table 1). Morpholino-mediated knockdown of Id.a resulted in ectopic expression and upregulation of Id.a itself, which suggests a negative autoregulatory feedback, either direct or indirect [63]. Moreover, morpholino-mediated knockdown of Neurog resulted in the loss of Id.a expression, suggesting that Id.a is downstream target of Neurog [63].

\subsection{Group E}

The bHLH TFs of group E are characterized by the presence of additional motifs in their C-terminal region: a YRPW (Tyr-Arg-Pro-Trp) motif in the Hey subclass, and a WRPW (Trp-Arg-Pro-Trp) motif in the Hairy and Enhancer of split $(\mathrm{E}(\mathrm{spl}))$ subclass [147]. In C. robusta, there is only one bHLH gene in the Hey subclass (Hey), and three genes that belong to the Hairy/ E(spl) subclass (Hes.a, Hes.b, and Hes.c) [147]. WMISH results show a weak expression of Hes.a in three parallel regions located in the dorsal portion of the SV wall [50]; the region showing the sharpest hybridization signal is depicted in Figure 3B. Expression of Hes.a in the SV wall is supported by scRNA-Seq data [31] [Table 1). Expression of Hes.b is discontinuous and encompasses all four structures of the larval CNS (Figure 3) [50]; in addition to being expressed in the CNS, Hes.b is expressed in the tail epidermis, in sharp dorsal and ventral medio-lateral domains [187]. Remarkably, after metamorphosis, Hes.b participates in the regeneration of the oral siphon (see above) [137].

\subsection{Group F}

The bHLH TFs of the phylogenetic group $\mathrm{F}$ are characterized by the presence of a COE (Collier/Olf-1/EBF) domain that is involved in dimerization and DNA binding [188]. Ebf is the only bHLH TF of C. robusta that meets the structural requirements of this group. Ebf exhibits a broad expression pattern in the SV and motor ganglion at the mid-tailbud stage [50]. The homolog of this gene in C. elegans, unc-3, is required for the regulation of the terminal differentiating features of cholinergic motor neurons, which suggests that the function of this TF has remained conserved throughout evolution [103]. In further support of this point, the expression of C. robusta Ebf is able to compensate for the loss of activity of unc-3 in C. elegans unc-3 mutants [103]. In addition to its function in the larval CNS of Ciona, Ebf is also responsible for establishing the pharyngeal muscle cell fate in 
mixed-fated cardiopharyngeal precursors, through the activation of another bHLH TF, Mrf, and for excluding the cardiac developmental program from these progenitors [189].

\subsection{Outgroup}

Four of the Ciona bHLH genes have been tentatively designated as 'tunicate $b H L H$ ' genes (Bhlh-tun1-4) because they seemed to lack identifiable counterparts in animals other than tunicates $[147,190]$. At least two of these genes are expressed in the SV, Bhlh-tun1 and Bhlh-tun2. Tunicate bHLH 1 (Bhlh-tun1) is expressed in the developing notochord, in the midline epidermis of trunk and tail, and in the SV $[50,166,191]$. The expression pattern of Bhlh-tun1 in the SV is quite dynamic, and encompasses various small groups of cells, predominantly located in the wall of the SV $[31,166]$ (our unpublished data). Single-cell RNA profiling results indicate expression in several additional SV cell types, including MHB and pigment cells [27]. Studies of its cis-regulatory region suggest that Bhlh-tun 1 is also expressed, in late larval stages, in the stomodeum and in the two atrial siphon primordia (Figure 3A) [166]. Before metamorphosis, Bhlh-tun1 is involved in the formation of the notochord and of the neurogenic midline [166,191]. After metamorphosis, Bhlh-tun1 participates in the formation of the musculature of both oral and atrial siphons [189,192]. The bHLH-tun1 protein consists of only 139 amino acid residues, half of which constitute the basic DNA-binding domain, and it does not group with any of the monophyletic bHLH groupings [147,166]. Bona fide orthologs of Bhlh-tun1 are yet to be identified in vertebrates, which suggests that this might be a tunicate-specific gene. Our laboratory's results on the DNA-binding properties of Bhlh-tun1 indicate that this short protein efficiently binds in vitro E-boxes with different cores [166]. After performing a subtractive microarray screen, we found that bHLH-tun1 is responsible for the transcriptional regulation of at least two genes expressed in the anteroventral SV, namely Lhx3/4/5, which encodes for a TF of the LIM homeobox family, and Gucyla1, whose product is a subunit of the guanylate cyclase enzymatic complex [166]. In humans, mutations in the LHX3 gene have been associated with combined pituitary hormone deficiency, limited neck rotation, and sensorineural hearing loss [193]. In other vertebrates, $L h x 3$ and $L h x 4$ have been reported to play redundant roles in the development of the adenohypophysis; mouse embryos harboring homozygous null alleles of $L h x 3$ and $L h x 4$ display arrested development of Rathke's pouch during early embryogenesis $[194,195]$. Lhx3 is also involved in the specification of motor neurons $[193,196]$. Studies in chick embryos revealed that $L h x 3$ expression is restricted to the medial subdivision of the motor columns of the spinal cord, whose motor neurons extend along the entire rostro-caudal length of the spinal cord and project to the axial muscle [196]. Accordingly, Ciona Lhx3/4/5 is expressed in the motor ganglion [63].

The guanylate cyclase enzymatic complex catalyzes the conversion of guanosine- 5 -triphosphate (GTP) to 3',5'-cyclic guanosine monophosphate (GMP) and pyrophosphate when stimulated by the gaseous signaling molecule nitric oxide (NO) [197]. The NO signaling pathway regulates the neuronal activity in distinct regions of the hypothalamus [197], and in ascidians is involved in the regulation of metamorphosis [198].

Expression of tunicate bHLH 2 (Bhlh-tun2) is localized to a small region of the ventral SV [108] (Figure 3B). This gene was originally categorized as tunicate-specific; however, current tBLASTN searches detected sequence homology between Bhlh-tun2 and Nhlh1, a group A bHLH TF [199]; we suggest that, in light of its sequence similarities, Bhlh-tun 2 could be tentatively assigned to this subdivision of the Ciona bHLH family. In mouse embryos, Nhlh1 has been recently described as a possible transcriptional regulator of Onecut1 in fate-restricted retinal progenitors [200]. In Ciona, Onecut is an activator of $R x$ expression in the SV, and controls development of the ocellus and its photoreceptors [201]; in turn, expression of Onecut is controlled by Neurog in most of its domains, with the notable exception of the SV [202]. Together, the role of Nhlh1 in mouse and the conservation of the function of Onecut in retinal development in Ciona suggest the intriguing possibility that Bhlh-tun2/Nhlh1 might be the still uncharacterized activator of Onecut expression. 
The expression pattern of Bhlh-tun3 is still uncharacterized; the hybridization signal for Bhlh-tun4 was not clearly localized [50].

An additional bHLH gene of uncertain classification is bHLH-like1 (Table 1), which is related to a bHLH TF called spermatogenesis- and oogenesis-specific bHLH-containing protein 1 (Sohlh1). This bHLH TF is expressed in both male and female mammalian germ cells. Together with other TFs, including the bHLH TFs Neurog3 and Sohlh2, Sohlh1 is part of a gene regulatory network that promotes spermatogonial differentiation in male mammals [203], and is required for oogenesis in females [204].

\section{Cross-Regulatory Interactions among bHLH Transcription Factors in Ciona}

Autoregulatory feedback and cross-regulatory interactions among transcription factors are major contributors in the generation of the regulatory state of a gene network [205]. In vertebrate organisms, these interactions link numerous bHLH TFs, often in tissue- and organ-specific cross-regulatory networks, as is the case for the bHLH TFs involved in the specification of the cell types present in the retina [206] or in the cochlea [207]. The results of gene inactivation experiments suggest that cross-regulation between bHLH TFs might be widespread in Ciona as well. In the nervous system, MO-mediated knockdown of Neurog resulted in reduced expression of Ebf in neural precursors [164]. The down-regulation of Neurog also caused an increment of its own mRNA levels, suggesting the existence of a negative autoregulatory loop, either direct or indirect [164]. In bipolar tail neurons, Neurog acts as a positive regulator of bHLH-tun2 expression [108]; these results suggest that the regulatory relationship between these bHLH TFs might be retained in the SV as well.

In the mesenchyme, the MO-mediated knockdown of Hand-r (NoTrl) resulted in the downregulation of both Twist-r.a and Twist-r.b [164]. Hand-r morphants also exhibited an increment in the mRNA levels of Hand-r, which suggests that a negative autoregulatory feedback might occur for this gene as well [164]. In the trunk ventral cells (TVCs), the heart precursors, the expression of Hand- $r$ is regulated by another bHLH TF, Mesp [22,160,164]. Mesp morphants also display an increase in Mesp transcription [164]. Similar results were observed in Mrf morphants [164], suggesting that negative autoregulatory feedback is a widespread characteristic of bHLH TFs.

Also in cardiopharyngeal precursors, another bHLH TF, Ebf, is able to promote the pharyngeal muscle fate by activating the muscle differentiation program downstream of Mrf [189].

In the epidermis, overexpression studies and results of microarray screens indicate that Bhlh-tun1 down-regulates Ascl.a and Hes.c [166,191]. In embryos overexpressing Bhlh-tun1 in the notochord, expression of Bhlh-tun1 itself is reduced, which provides another example of a bHLH TF fine-tuning its own transcription [166].

\section{Conclusions}

Differently from developmental regulators of the homeodomain family, which pattern the body plan along its anterior-posterior and proximal-distal axes across metazoan, transcription factors of the bHLH superfamily are often involved in cell-lineage determination and cell differentiation. In ascidians and vertebrates alike, bHLH TFs are required, in particular, for the regulation of both myogenesis and neurogenesis. During vertebrate neurogenesis, bHLH TFs, which are frequently present in these complex genomes in multiple copies, act in a partially redundant fashion to generate neuronal diversity within the main subdivision of the developing nervous system. Despite being several orders of magnitude less complex than a vertebrate brain, the CNS of Ciona expresses at least 21 different bHLH TFs within the roughly 330 neural and non-neural cells that compose its four anatomical compartments. A large fraction of these genes are expressed in partially overlapping territories, and this suggests that their products can form different heterodimers with varying transcriptional activity. In turn, different heterodimers, and the target genes that they control, are potentially able to generate sub-domains of neural gene expression within the Ciona CNS. The results of gene expression studies reviewed here suggest that some of these molecular compartments could be regarded as predecessors of structures 
that are anatomically and physiologically distinguishable in the vertebrate brain, such as hypothalamus and retina.

In addition to the physical interactions shared by different bHLH TFs through the formation of heterodimers, these factors are also largely interconnected at the transcriptional level by cross-regulatory interactions. Consequently, the expansion of the complement of bHLH genes and their respective cis-regulatory regions that accompanied vertebrate evolution has not only widened the repertoire of possible bHLH dimers, but has also increased the intricacy of the network of cross-regulatory interconnections that existed in invertebrate chordates. A few examples of these interconnections have already been identified in Ciona, and additional ones will likely be discovered as more functional studies of bHLH genes are performed in this organism.

Another mechanism that, during vertebrate evolution, has led to the appearance of structures that were not present in invertebrate chordates, the so-called 'vertebrate innovations', is the co-option of existing transcription factors, and their respective downstream genes, to different or novel cell types. Studies in Ciona suggest that bHLH TFs that mediate epithelial-mesenchymal transition and cell migration, as well as the bHLH TFs that participate in the melanocyte-specific gene regulatory network, were present in a common chordate ancestor. Their co-option to emerging cell types might have represented a key event in the appearance of migrating neural crest cells and their derivatives, which include the vertebrate craniofacial structures. In a similar way, the increasing intersections among the territories of expression of bHLH TFs, and the expansion of their cross-regulatory network, likely drove the emergence of novel anatomical structures and shaped functional compartments in the vertebrate brain. 
Table 1. Genes encoding transcription factors of the bHLH family in the ascidian Ciona robusta.

\begin{tabular}{|c|c|c|c|c|c|c|c|}
\hline \multirow{2}{*}{ Gene Name } & \multirow{2}{*}{ Alternative Names } & \multirow{2}{*}{ Human Hits * } & \multirow{2}{*}{$\begin{array}{l}\text { Gene Models } \\
\text { KH2013 } \\
\text { KY2019 }\end{array}$} & \multirow{2}{*}{$\begin{array}{c}\text { Expression at } \\
\text { Mid/Late Tailbud }\end{array}$} & \multirow{2}{*}{ Reference } & \multicolumn{2}{|c|}{ scRNA-Seq Data from Larvae } \\
\hline & & & & & & [27] & [31] \\
\hline $\begin{array}{l}\text { Ascl.a (achaete-scute } \\
\text { family bHLH } \\
\text { transcription factor.a) }\end{array}$ & Achaete-Scute a-like2 & $\begin{array}{c}\text { ASCL1; } \\
\text { ASCL3; ASCL5 }\end{array}$ & $\begin{array}{c}\text { KH.L9.13 } \\
\text { KY.Chr2.2314 }\end{array}$ & Epid., palps & [50] & & \\
\hline $\begin{array}{l}\text { Ascl.b (achaete-scute } \\
\text { family bHLH } \\
\text { transcription factor.b) }\end{array}$ & Achaete-Scute b & $\begin{array}{c}\text { ASCL3; } \\
\text { ASCL4; ASCL5 }\end{array}$ & $\begin{array}{c}\text { KH.C2.880 } \\
\text { KY.Chr2.2022 }\end{array}$ & ESNs & [163] & & \\
\hline $\begin{array}{l}\text { Ascl.c (achaete-scute } \\
\text { family bHLH } \\
\text { transcription factor.c) }\end{array}$ & Achaete-Scute a-like1 & $\begin{array}{c}\text { ASCL3; } \\
\text { ASCL5; } \\
\text { NEUROD1 }\end{array}$ & $\begin{array}{l}\text { KH.C2.560 } \\
\text { KY.Chr2.1484 }\end{array}$ & $\begin{array}{l}\text { Anterior SV, } \\
\text { weak mesench. } \\
\text { and palps }\end{array}$ & [50]; Figure 3 & & \\
\hline $\begin{array}{l}\text { Atoh8 (Atonal bHLH } \\
\text { transcription factor } 8 \text { ) }\end{array}$ & Net; NeuroD-like & $\begin{array}{c}\text { ATOH1; } \\
\text { ATOH8; } \\
\text { NEUROD4 } \\
\end{array}$ & $\begin{array}{l}\text { KH.C9.872 } \\
\text { KY.Chr9.174 }\end{array}$ & $\begin{array}{l}\text { Anterior SV, MG, } \\
\text { cESNs, trunk endod. }\end{array}$ & $\begin{array}{c}{[50,84]} \\
\text { Figure } 3\end{array}$ & aSV & Ventral SV \\
\hline Atonal & & $\begin{array}{c}\text { ATOH1; } \\
\text { ATOH7; } \\
\text { NEUROD1 }\end{array}$ & $\begin{array}{c}\text { KH.C8.175 } \\
\text { KY.Chr8.248 }\end{array}$ & ESNs, palps & {$[50]$} & $\begin{array}{l}\text { cESNs } \\
\text { rTENs }\end{array}$ & \\
\hline $\begin{array}{c}\text { Bhlha15 (basic } \\
\text { helix-loop-helix family } \\
\text { member a15) }\end{array}$ & Mist & $\begin{array}{l}\text { BHLHA15; } \\
\text { NEUROG1; } \\
\text { NEUROG2 }\end{array}$ & $\begin{array}{c}\text { KH.C3.308 } \\
\text { KY.Chr3.1309 }\end{array}$ & Mesench. & {$[50]$} & & \\
\hline $\begin{array}{l}\text { Hand (heart and neural } \\
\text { crest derivatives } \\
\text { expressed) }\end{array}$ & & $\begin{array}{l}\text { HAND1; } \\
\text { HAND2; } \\
\text { TCF15 }\end{array}$ & $\begin{array}{l}\text { KH.C14.604 } \\
\text { KY.Chr14.359 }\end{array}$ & Mesench. & {$[50]$} & & \\
\hline $\begin{array}{c}\text { Hand-r (heart and neural } \\
\text { crest derivatives } \\
\text { expressed-related) }\end{array}$ & NoTrlc & $\begin{array}{c}\text { HAND1; } \\
\text { HAND2; SCX }\end{array}$ & $\begin{array}{l}\text { KH.C1.1116 } \\
\text { KY.Chr1.2070 }\end{array}$ & Mesench., TVCs, SV & [164]; Figure 3 & & \\
\hline $\begin{array}{l}\text { Mesp (mesoderm } \\
\text { posterior bHLH } \\
\text { transcription factor) }\end{array}$ & & $\begin{array}{l}\text { MESP2; } \\
\text { MSGN1; } \\
\text { PTF1A }\end{array}$ & $\begin{array}{l}\text { KH.C3.100 } \\
\text { KY.Chr3.993 }\end{array}$ & $\begin{array}{l}\text { Anterior ventral } \\
\text { primary muscle, } \\
\text { TVCs }\end{array}$ & [159] & & \\
\hline $\begin{array}{l}\text { Mrf (Myogenic } \\
\text { regulatory factor) }\end{array}$ & MyoD; CiMDFa & $\begin{array}{l}\text { MYF5; MYF6; } \\
\text { MYOD1 }\end{array}$ & $\begin{array}{l}\text { KH.C14.307 } \\
\text { KY.Chr14.1058 }\end{array}$ & Muscle & [156] & & \\
\hline
\end{tabular}


Table 1. Cont.

\begin{tabular}{|c|c|c|c|c|c|c|c|}
\hline \multirow{2}{*}{ Gene Name } & \multirow{2}{*}{ Alternative Names } & \multirow{2}{*}{ Human Hits * } & \multirow{2}{*}{$\begin{array}{c}\text { Gene Models } \\
\text { KH2013 } \\
\text { KY2019 }\end{array}$} & \multirow{2}{*}{$\begin{array}{c}\text { Expression at } \\
\text { Mid/Late Tailbud }\end{array}$} & \multirow{2}{*}{ Reference } & \multicolumn{2}{|c|}{ scRNA-Seq Data from Larvae } \\
\hline & & & & & & [27] & [31] \\
\hline Neurog (Neurogenin) & & $\begin{array}{l}\text { NEUROG1; } \\
\text { NEUROG2; } \\
\text { NEUROG3 }\end{array}$ & $\begin{array}{l}\text { KH.C6.129 } \\
\text { KY.Chr6.427 }\end{array}$ & $\begin{array}{c}\text { SV, MG, NC } \\
\text { Atrial ectoderm }\end{array}$ & $\begin{array}{l}{[50,147,208]} \\
\text { Figure } 3\end{array}$ & $\begin{array}{l}\text { aATENs, aSV, } \\
\text { MHB, SV, MG, } \\
\text { Epend. }\end{array}$ & $\begin{array}{l}\text { Dorsolat. SV; } \\
\text { SV wall }\end{array}$ \\
\hline $\begin{array}{l}\text { Ptf1a (pancreas associated } \\
\text { transcription factor } 1 a \text { ) }\end{array}$ & Ptfa & $\begin{array}{c}\text { not } \\
\text { determined }\end{array}$ & $\begin{array}{c}\text { KH.C3.967 } \\
\text { KY.Chr3.526 }\end{array}$ & SV & [165]; Figure 3 & & \\
\hline $\begin{array}{l}\text { Ptf1a-r (pancreas } \\
\text { associated transcription } \\
\text { factor 1a-related) }\end{array}$ & $P t f b$ & $\begin{array}{c}\text { not } \\
\text { determined }\end{array}$ & $\begin{array}{l}\text { KH.L116.39 } \\
\text { KY.Chr11.543 }\end{array}$ & SV & [50]; Figure 3 & Coronet cells & Ventral SV \\
\hline $\begin{array}{c}\text { Tcf3 } \\
\text { (transcription factor } 3 \text { ) }\end{array}$ & $E 12 / E 47 E 2 A$ & $\begin{array}{c}\text { not } \\
\text { determined }\end{array}$ & $\begin{array}{c}\text { KH.C3.480 } \\
\text { KY.Chr3.781 }\end{array}$ & $\begin{array}{c}\text { Diffuse signal, } \\
\text { predominant in SV }\end{array}$ & [50]; Figure 3 & & \\
\hline $\begin{array}{l}\text { Tcf15-r (transcription } \\
\text { factor 15-related) }\end{array}$ & Paraxis-like & $\begin{array}{l}\text { SCX; TAL2; } \\
\text { TCF15 }\end{array}$ & $\begin{array}{c}\text { KH.S781.11 } \\
\text { KY.Chr11.73 }\end{array}$ & No expression & [160] & & \\
\hline $\begin{array}{l}\text { Twist-r.a (twist family } \\
\text { bHLH transcription } \\
\text { factor-related.a) }\end{array}$ & Twist-like-1a & $\begin{array}{c}\text { ATOH1; } \\
\text { NEUROD6; } \\
\text { PTF1A }\end{array}$ & $\begin{array}{l}\text { KH.C5.416 } \\
\text { KY.Chr5.356 }\end{array}$ & TLCs & [164] & & \\
\hline $\begin{array}{l}\text { Twist-r.b (twist family } \\
\text { bHLH transcription } \\
\text { factor-related.b) }\end{array}$ & Twist-like-1b & $\begin{array}{c}\text { ATOH1; } \\
\text { NEUROD6; } \\
\text { NEUROG2 }\end{array}$ & $\begin{array}{l}\text { KH.C5.554 } \\
\text { KY.Chr5.355 }\end{array}$ & Mesench. & [124] & & \\
\hline $\begin{array}{l}\text { Twist-r.c (twist family } \\
\text { bHLH transcription } \\
\text { factor-related.c) }\end{array}$ & Twist-like-2 & $\begin{array}{l}\text { TAL2; TWIST1; } \\
\text { TWIST2 }\end{array}$ & $\begin{array}{l}\text { KH.C5.202 } \\
\text { KY.Chr5.357 }\end{array}$ & Mesench., TLCs & [50] & & Mesench. \\
\hline $\begin{array}{c}\text { AP4 (transcription factor } \\
A P-4)\end{array}$ & & $\begin{array}{l}\text { SREBF1; } \\
\text { TFAP4; } \\
\text { TWIST1 }\end{array}$ & $\begin{array}{l}\text { KH.C14.448 } \\
\text { KY.Chr14.930 }\end{array}$ & Mesench., SV & [50]; Figure 3 & & \\
\hline $\begin{array}{c}\text { Figla-r (Folliculogenesis } \\
\text { specific bHLH } \\
\text { transcription } \\
\text { factor-related) }\end{array}$ & & $\begin{array}{c}\text { FIGLA; } \\
\text { NHLH1; TAL2 }\end{array}$ & $\begin{array}{c}\text { KH.C2.1152 } \\
\text { KY.Chr2.2108 }\end{array}$ & Not analyzed & & & \\
\hline
\end{tabular}


Table 1. Cont.

\begin{tabular}{|c|c|c|c|c|c|c|c|}
\hline \multirow{2}{*}{ Gene Name } & \multirow{2}{*}{ Alternative Names } & \multirow{2}{*}{ Human Hits * } & \multirow{2}{*}{$\begin{array}{c}\text { Gene Models } \\
\text { KH2013 } \\
\text { KY2019 } \\
\end{array}$} & \multirow{2}{*}{$\begin{array}{c}\text { Expression at } \\
\text { Mid/Late Tailbud }\end{array}$} & \multirow{2}{*}{ Reference } & \multicolumn{2}{|c|}{ scRNA-Seq Data from Larvae } \\
\hline & & & & & & [27] & [31] \\
\hline $\begin{array}{c}\text { Mad (Mothers against } \\
\text { dpp) }\end{array}$ & Noto7 & $\begin{array}{l}\text { MXD1; MXD4; } \\
\text { MXI1 }\end{array}$ & $\begin{array}{c}\text { KH.C1.661 } \\
\text { KY.Chr1.761 }\end{array}$ & $\begin{array}{c}\text { SV, MG, palps, } \\
\text { notochord, tail epid., } \\
\text { tail muscles }\end{array}$ & {$[50,179]$} & $\begin{array}{l}\text { Neurons, } \\
\text { notochord }\end{array}$ & $\begin{array}{c}\text { Dorsolat. SV, } \\
\text { ventral SV, } \\
\text { Endod., Epid. }\end{array}$ \\
\hline $\begin{array}{c}\text { Max (Myc associated } \\
\text { factor X) }\end{array}$ & & $\begin{array}{c}\text { Not } \\
\text { determined }\end{array}$ & $\begin{array}{l}\text { KH.C5.373 } \\
\text { KY.Chr5.121 }\end{array}$ & Mesench. & [50] & ANB, aSV, MG & $\begin{array}{l}\text { Epid., } \\
\text { Mesench., } \\
\text { Endod. }\end{array}$ \\
\hline $\begin{array}{c}\text { Mitf } \\
\text { (Microphthalmia-associated } \\
\text { transcription factor) }\end{array}$ & & $\begin{array}{l}\text { MITF; TFE3; } \\
\text { TFEB }\end{array}$ & $\begin{array}{c}\text { KH.C10.106 } \\
\text { KY.Chr10.837 }\end{array}$ & $\begin{array}{c}\text { Mesench., } \\
\text { pigmented cells } \\
\text { (otolith, ocellus), } \\
\text { MG }\end{array}$ & $\begin{array}{l}{[50,120] ;} \\
\text { Figure } 3\end{array}$ & $\begin{array}{l}\text { Collocytes } \\
\text { aATENs }\end{array}$ & Epid. \\
\hline Mlx (Max-like protein $x)$ & & $\begin{array}{l}\text { MLXIP; } \\
\text { MLXIPL }\end{array}$ & $\begin{array}{c}\text { KH.C11.706 } \\
\text { KY.Chr11.477 }\end{array}$ & Mesench. & {$[50]$} & & \\
\hline $\begin{array}{l}\text { Mnt-r (Max network } \\
\text { transcriptional } \\
\text { repressor-related) }\end{array}$ & Mnt-like & $\begin{array}{l}\text { MNT; MXD1; } \\
\text { MXD3 }\end{array}$ & $\begin{array}{l}\text { KH.L20.34 } \\
\text { KY.Chr6.608 }\end{array}$ & $\begin{array}{l}\text { No expression; a } \\
\text { faint signal in SV, } \\
\text { palps and mesench. } \\
\text { might be present in } \\
\text { late tailbuds }\end{array}$ & [50] & & \\
\hline Myc (Myelocytomatosis) & & $\begin{array}{l}\text { MNT; MYC; } \\
\text { MYCN }\end{array}$ & $\begin{array}{l}\text { KH.L24.23 } \\
\text { KY.Chr1.686 }\end{array}$ & $\begin{array}{l}\text { Mesench., anterior } \\
\text { SV, trunk endod.; in } \\
\text { juveniles: endostyle } \\
\text { pharyngeal gills, } \\
\text { heart, intestine, } \\
\text { body wall muscle, } \\
\text { neural gland } \\
\text { epidermis, stomach, } \\
\text { esophagus }\end{array}$ & $\begin{array}{l}{[50,145]} \\
\text { Figure } 3\end{array}$ & ANB & Endod., Epid. \\
\hline $\begin{array}{l}\text { Srebp (Sterol regulatory } \\
\text { element-binding } \\
\text { transcription factor } 1)\end{array}$ & & $\begin{array}{l}\text { SREBF1; } \\
\text { SREBF2 }\end{array}$ & $\begin{array}{l}\text { KH.L99.12 } \\
\text { KY.Chr9.7 }\end{array}$ & $\begin{array}{l}\text { SV, palps; epid. } \\
\quad \text { (in larvae) }\end{array}$ & $\begin{array}{l}{[50,141]} \\
\text { Figure } 3\end{array}$ & $\mathrm{NC}$ & $\begin{array}{c}\text { SV wall, } \\
\text { ventral SV }\end{array}$ \\
\hline $\begin{array}{c}\text { Usf (Upstream } \\
\text { transcription factor) }\end{array}$ & & $\begin{array}{l}\text { USF1; USF2; } \\
\text { USF3 }\end{array}$ & $\begin{array}{c}\text { KH.C3.624 } \\
\text { KY.Chr3.1438 }\end{array}$ & $\begin{array}{c}\text { Mesench., } \\
\text { faint signal in SV } \\
\text { and NC }\end{array}$ & [50]; Figure 3 & & $\begin{array}{c}\text { Dorsolat. SV, } \\
\text { Mesench., } \\
\text { Epid. }\end{array}$ \\
\hline
\end{tabular}


Table 1. Cont.

\begin{tabular}{|c|c|c|c|c|c|c|c|}
\hline \multirow{2}{*}{ Gene Name } & \multirow{2}{*}{ Alternative Names } & \multirow{2}{*}{ Human Hits * } & \multirow{2}{*}{$\begin{array}{c}\text { Gene Models } \\
\text { KH2013 } \\
\text { KY2019 }\end{array}$} & \multirow{2}{*}{$\begin{array}{c}\text { Expression at } \\
\text { Mid/Late Tailbud }\end{array}$} & \multirow{2}{*}{ Reference } & \multicolumn{2}{|c|}{ scRNA-Seq Data from Larvae } \\
\hline & & & & & & [27] & [31] \\
\hline $\begin{array}{c}\text { AHR (Aryl hydrocarbon } \\
\text { receptor) }\end{array}$ & & $\begin{array}{l}\text { AHR; AHRR; } \\
\quad \text { SIM2 }\end{array}$ & $\begin{array}{c}\text { KH.C12.93 } \\
\text { KY.Chr12.869 }\end{array}$ & Mesench., palps, NC & [50] & $\begin{array}{l}\text { Collocytes } \\
\text { aATENs }\end{array}$ & Epid. \\
\hline $\begin{array}{c}\text { ARNT (Aryl } \\
\text { hydrocarbon receptor } \\
\text { nuclear translocator) }\end{array}$ & & $\begin{array}{l}\text { ARNT; } \\
\text { ARNT2; } \\
\text { ARNTL }\end{array}$ & $\begin{array}{l}\text { KH.C5.213 } \\
\text { KY.Chr5.617 }\end{array}$ & $\begin{array}{l}\text { Weak mesench., } \\
\text { notochord, unclear } \\
\text { signal in epidermis; } \\
\text { in juveniles: } \\
\text { endostyle } \\
\text { pharyngeal gills, } \\
\text { neural gland, } \\
\text { stomach, esophagus }\end{array}$ & {$[50,136,180]$} & & \\
\hline $\begin{array}{l}\text { Hif (Hypoxia inducible } \\
\text { factor) }\end{array}$ & & $\begin{array}{l}\text { EPAS1; HIF1A; } \\
\text { HIF3A }\end{array}$ & $\begin{array}{c}\text { KH.C4.83 } \\
\text { KY.Chr4.583 }\end{array}$ & $\begin{array}{l}\text { Mesench., anterior } \\
\text { SV, palps, ventral } \\
\text { midline, tail epid.; in } \\
\text { juveniles: endostyle } \\
\text { pharyngeal gills, } \\
\text { heart, intestine, } \\
\text { body wall muscle, } \\
\text { neural gland } \\
\text { epidermis, stomach, } \\
\text { esophagus }\end{array}$ & $\begin{array}{l}{[30,50] ;} \\
\text { Figure } 3\end{array}$ & aSV & \\
\hline Sim (Single-minded) & & $\begin{array}{c}\text { Not } \\
\text { determined }\end{array}$ & $\begin{array}{c}\text { KH.L20.56 } \\
\text { KY.Chr6.618 }\end{array}$ & Not analyzed & & & \\
\hline Trh (Trachealess) & & $\begin{array}{c}\text { NPAS1; } \\
\text { NPAS3; SIM2 }\end{array}$ & $\begin{array}{c}\text { KH.L154.23 } \\
\text { KY.Chr11.674 }\end{array}$ & $\begin{array}{c}\text { Mesench., very weak } \\
\text { SV }\end{array}$ & [50] & & \\
\hline $\begin{array}{c}\text { Id.a (inhibitor of DNA } \\
\text { binding.a) }\end{array}$ & Emc & ID2; ID3 & $\begin{array}{c}\text { KH.C7.692 } \\
\text { KY.Chr7.1153 }\end{array}$ & Not analyzed & & & $\begin{array}{l}\text { SV wall, } \\
\text { mesench., } \\
\text { epid. }\end{array}$ \\
\hline $\begin{array}{l}\text { Id.b (inhibitor of DNA } \\
\text { binding.b) }\end{array}$ & Emc2 & ID1; ID2; ID3 & $\begin{array}{c}\text { KH.C7.157 } \\
\text { KY.Chr7.1157 }\end{array}$ & $\begin{array}{l}\text { SV, MG, NC; palps, } \\
\text { tail epid., ESNs }\end{array}$ & [50] & NC, aSV & $\begin{array}{l}\text { SV wall, } \\
\text { ventral SV, } \\
\text { Endod., } \\
\text { Mesench. }\end{array}$ \\
\hline
\end{tabular}


Table 1. Cont.

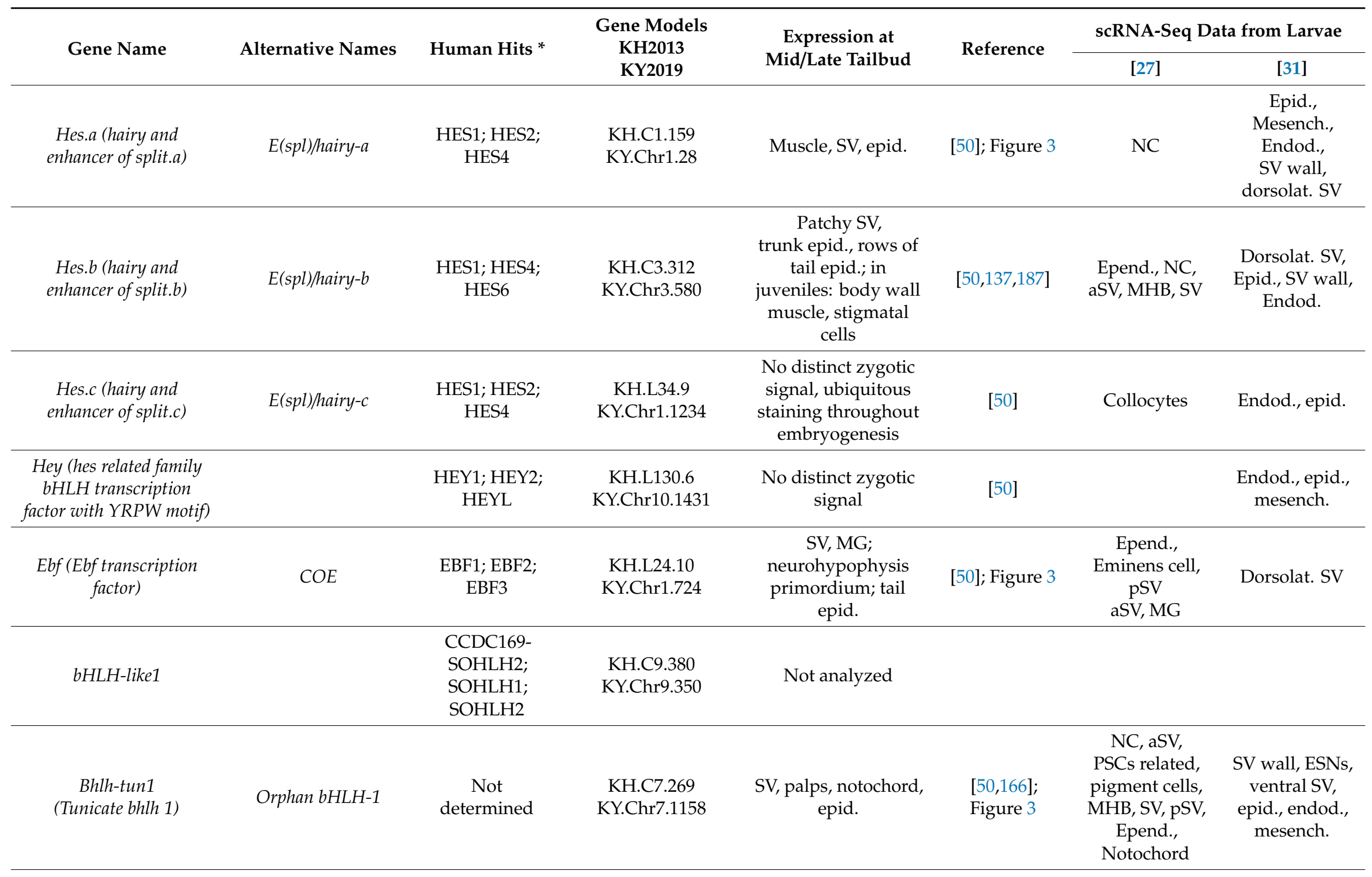


Table 1. Cont.

\begin{tabular}{|c|c|c|c|c|c|c|c|}
\hline \multirow{2}{*}{ Gene Name } & \multirow{2}{*}{ Alternative Names } & \multirow{2}{*}{ Human Hits * } & \multirow{2}{*}{$\begin{array}{c}\text { Gene Models } \\
\text { KH2013 } \\
\text { KY2019 }\end{array}$} & \multirow{2}{*}{$\begin{array}{c}\text { Expression at } \\
\text { Mid/Late Tailbud }\end{array}$} & \multirow{2}{*}{ Reference } & \multicolumn{2}{|c|}{ scRNA-Seq Data from Larvae } \\
\hline & & & & & & [27] & [31] \\
\hline $\begin{array}{c}\text { Bhlh-tun2 } \\
\text { (Tunicate bhlh 2) }\end{array}$ & Orphan bHLH-2 & $\begin{array}{c}\text { NHLH1; } \\
\text { NHLH2; TAL2 }\end{array}$ & $\begin{array}{c}\text { KH.C4.649 } \\
\text { KY.Chr4.1008 }\end{array}$ & SV, BTNs, mesench. & $\begin{array}{l}{[50,108] ;} \\
\text { Figure } 3\end{array}$ & $\begin{array}{c}\text { aSV, MG, } \\
\text { Eminens cell }\end{array}$ & Dorsolat. SV \\
\hline $\begin{array}{c}\text { Bhlh-tun3 } \\
\text { (Tunicate bhlh 3) }\end{array}$ & Orphan bHLH-3 & $\begin{array}{c}\text { Not } \\
\text { determined }\end{array}$ & KY.Chr10.1238 & Not analyzed & & & \\
\hline $\begin{array}{c}\text { Bhlh-tun4 } \\
\text { (Tunicate bhlh 4) }\end{array}$ & Orphan bHLH-4 & $\begin{array}{c}\text { Not } \\
\text { determined }\end{array}$ & $\begin{array}{c}\text { KH.L41.39 } \\
\text { KY.Chr4.1211 }\end{array}$ & $\begin{array}{c}\text { No distinct zygotic } \\
\text { signal }\end{array}$ & [50] & & \\
\hline $\begin{array}{c}\text { Tcf4 } 4 \\
\text { (transcription factor } 4 \text { ) }\end{array}$ & & $\begin{array}{l}\text { TFDP1; TFDP2; } \\
\text { TFDP3 }\end{array}$ & $\begin{array}{l}\text { KH.L60.12 } \\
\text { KY.Chr1.10 }\end{array}$ & $\begin{array}{c}\text { No distinct zygotic } \\
\text { signal; weak } \\
\text { mesench. } \\
\text { throughout } \\
\text { embryogenesis }\end{array}$ & [50] & & \\
\hline
\end{tabular}


Table 2. Classification of bHLH genes in the ascidian Ciona robusta. Modified from $[147,148]$.

\begin{tabular}{|c|c|c|}
\hline Phylogenetic Group & Characteristics & C. robusta bHLH Genes \\
\hline $\mathrm{A}$ & Bind to CAGCTG or CACCTG & $\begin{array}{c}\text { Ascl.a, Ascl.b, Ascl.c }{ }^{*}, \text { Atohs }{ }^{*} \text {, Atonal, Bhlha15, } \\
\text { Hand, Hand- } r \text { *, Mesp, Mrf, Neurog }{ }^{*}, \text { Ptf1a }{ }^{*}, \\
\text { Ptf1a-r }{ }^{*}, \text { Tcf } 3^{*}, \text { Tcf15-r, Twist-r.a, Twist-r.b, Twist-r.c }\end{array}$ \\
\hline B & Bind to CACGTG or CATGTTG & 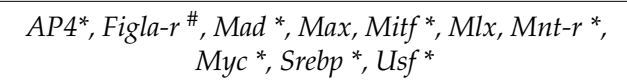 \\
\hline $\mathrm{C}$ & $\begin{array}{l}\text { Bind to ACGTG or GCGTG. } \\
\text { Contain a PAS domain }\end{array}$ & AHR, ARNT, Hif* ${ }^{*}$ Sim $^{\#}$, Trh \\
\hline $\mathrm{D}$ & $\begin{array}{l}\text { Lack basic domain and do not bind } \\
\text { to DNA. Act as antagonists of } \\
\text { group A bHLH proteins }\end{array}$ & Id. $a^{\#}, I d . b^{*}$ \\
\hline $\mathrm{E}$ & $\begin{array}{l}\text { Contain an orange domain and a } \\
\text { WRPW peptide }\end{array}$ & Hes. $a *$, Hes. $b^{*}$, Hes.c, Hey \\
\hline $\mathrm{F}$ & $\begin{array}{c}\text { Contain an additional COE domain, } \\
\text { which is involved in dimerization } \\
\text { and DNA binding }\end{array}$ & $E b f^{*}$ \\
\hline Outgroup & & $\begin{array}{c}\text { Bhlh-tun1 }{ }^{*} \text {, Bhlh-tun2*, Bhlh-tun3 }{ }^{\#} \\
\text { Bhlh-tun4 Uncertain classification: bHLH-like1 }\end{array}$ \\
\hline
\end{tabular}

Author Contributions: L.J.N.-P. conceived and created the figures and wrote the first drafts of the manuscript. Y.W. contributed to the figures, selected, and organized bibliography, and provided input on the manuscript. A.D.G. contributed to the creation of the figures and expanded the manuscript. All authors have read and agreed to the published version of the manuscript.

Funding: Research in our lab is supported by the Eunice Kennedy Shriver National Institute of Child Health and Human Development of the National Institutes of Health, under award number R03HD098395. LJN-P is supported by NIH training grant T32HD007520.

Conflicts of Interest: The authors declare no conflict of interest.

\section{Abbreviations}

$\begin{array}{ll}\text { ANR } & \text { anterior neural ridge; } \\ \text { bHLH } & \text { basic helix-loop-helix } \\ \text { BTN } & \text { bipolar tail neuron } \\ \text { CNS } & \text { central nervous system; } \\ \text { FGF } & \text { Fibroblast growth factor } \\ \text { GMP } & 3^{\prime}, 5^{\prime} \text {-cyclic guanosine monophosphate } \\ \text { GTP } & \text { guanosine-5'-triphosphate } \\ \text { hr(s) } & \text { hour(s); } \\ \text { kb } & \text { kilobase(s), or 1000 base pairs; } \\ \text { MG } & \text { motor ganglion; } \\ \text { MHB } & \text { midbrain-hindbrain boundary; } \\ \text { MO } & \text { morpholino oligonucleotide; } \\ \text { NC } & \text { nerve cord; } \\ \text { SV } & \text { sensory vesicle; } \\ \text { TF(s) } & \text { transcription factor(s); } \\ \text { WMISH } & \text { whole-mount in situ hybridization; } \\ \text { ZLI } & \text { zona limitans intrathalamica. }\end{array}$

\section{References}

1. Delsuc, F.; Brinkmann, H.; Chourrout, D.; Philippe, H. Tunicates and not cephalochordates are the closest living relatives of vertebrates. Nature 2006, 439, 965-968. [CrossRef] [PubMed] 
2. Chabry, L. Contribution a l'embryologie normale et teratologique des Ascidies simples. J. Anat. Physiol. 1887, 23, 167-319.

3. Conklin, E.G. The organization and cell-lineage of the ascidian egg. Acad. Nat. Sci. 1905. [CrossRef]

4. Lawrence, P.A.; Levine, M. Mosaic and regulative development: Two faces of one coin. Curr. Biol. 2006, 16, R236-R239. [CrossRef] [PubMed]

5. Ortolani, G. Risultati definitivi sulla distribuzione dei territory presuntivi degli organi nel germe di Ascidie allo stadio VIII, determinati con le marche al carbone. Section II: History and Philosophy of the Life Sciences. Pubbl. Stn. Zool. Napoli 1954, 25, 161-187.

6. Anderson, H.E.; Christiaen, L. Ciona as a Simple Chordate Model for Heart Development and Regeneration. J. Cardiovasc. Dev. Dis. 2016, 3, 25. [CrossRef]

7. Horie, R.; Hazbun, A.; Chen, K.; Cao, C.; Levine, M.; Horie, T. Shared evolutionary origin of vertebrate neural crest and cranial placodes. Nature 2018, 560, 228-232. [CrossRef]

8. Lemaire, P.; Smith, W.C.; Nishida, H. Ascidians and the Plasticity of the Chordate Developmental Program. Curr. Biol. 2008, 18, R620-R631. [CrossRef]

9. Satoh, N. Developmental Biology of Ascidians; Cambridge University Press: Cambridge, UK, 1994.

10. Satoh, N. The ascidian tadpole larva: Comparative molecular development and genomics. Nat. Rev. Genet. 2003, 4, 285-295. [CrossRef] [PubMed]

11. Jiang, D.; Smith, W.C. Ascidian notochord morphogenesis. Dev. Dyn. 2007, 236, 1748-1757. [CrossRef]

12. Di Gregorio, A. The notochord gene regulatory network in chordate evolution: Conservation and divergence from Ciona to vertebrates. Curr. Top. Dev. Biol. 2020, 139, 325-374. [CrossRef] [PubMed]

13. Maguire, J.E.; Pandey, A.; Wu, Y.; Di Gregorio, A. Investigating Evolutionarily Conserved Molecular Mechanisms Controlling Gene Expression in the Notochord. Adv. Exp. Med. Biol. 2018, 1029, 81-99. [CrossRef] [PubMed]

14. Corbo, J.C.; Erives, A.; Di Gregorio, A.; Chang, A.; Levine, M. Dorsoventral patterning of the vertebrate neural tube is conserved in a protochordate. Development 1997, 124, 2335-2344. [PubMed]

15. Hashimoto, H.; Robin, F.B.; Sherrard, K.M.; Munro, E. Sequential Contraction and Exchange of Apical Junctions Drives Zippering and Neural Tube Closure in a Simple Chordate. Dev. Cell 2015, 32, 241-255. [CrossRef] [PubMed]

16. Imai, K.S.; Satoh, N.; Satou, Y. Region specific gene expressions in the central nervous system of the ascidian embryo. Mech. Dev. 2002, 119 (Suppl. 1), S275-S277. [CrossRef]

17. Meinertzhagen, I.A.; Okamura, Y. The larval ascidian nervous system: The chordate brain from its small beginnings. Trends Neurosci. 2001, 24, 401-410. [CrossRef]

18. Stolfi, A.; Gainous, T.B.; Young, J.J.; Mori, A.; Levine, M.; Christiaen, L. Early Chordate Origins of the Vertebrate Second Heart Field. Science 2010, 329, 565-568. [CrossRef]

19. Tolkin, T.; Christiaen, L. Development and Evolution of the Ascidian Cardiogenic Mesoderm. Curr. Top. Dev. Biol. 2012, 100, 107-142. [CrossRef]

20. Razy-Krajka, F.; Gravez, B.; Kaplan, N.; Racioppi, C.; Wang, W.; Christiaen, L. An FGF-driven feed-forward circuit patterns the cardiopharyngeal mesoderm in space and time. ELife 2018, 7. [CrossRef]

21. Wang, B.T.; Yu, X.Y.; Zhu, Y.J.; Zhuang, M.; Zhang, Z.M.; Jin, L.; Jin, F.J. Research progress on the basic helix-loop-helix transcription factors of Aspergillus species. Adv. Appl. Microbiol. 2019, 109, 31-59. [CrossRef]

22. Racioppi, C.; A Wiechecki, K.A.; Christiaen, L. Combinatorial chromatin dynamics foster accurate cardiopharyngeal fate choices. ELife 2019, 8, e49921. [CrossRef] [PubMed]

23. Patricolo, E.; Cammarata, M.; D'Agati, P. Presence of thyroid hormones in ascidian larvae and their involvement in metamorphosis. J. Exp. Zoöl. 2001, 290, 426-430. [CrossRef]

24. Nakayama, S.; Ogasawara, M. Compartmentalized expression patterns of pancreatic- and gastric-related genes in the alimentary canal of the ascidian Ciona intestinalis: Evolutionary insights into the functional regionality of the gastrointestinal tract in Olfactores. Cell Tissue Res. 2017, 370, 113-128. [CrossRef]

25. Thompson, J.M.; Di Gregorio, A. Insulin-like genes in ascidians: Findings in Ciona and hypotheses on the evolutionary origins of the pancreas. Genesis 2015, 53, 82-104. [CrossRef] [PubMed]

26. Capellini, T.D.; Dunn, M.P.; Passamaneck, Y.J.; Selleri, L.; Di Gregorio, A. Conservation of notochord gene expression across chordates: Insights from theLeprecangene family. Genesis 2008, 46, 683-696. [CrossRef] [PubMed] 
27. Cao, C.; Lemaire, L.A.; Yoon, P.H.; Choi, Y.A.; Parsons, L.R.; Matese, J.C.; Wang, W.; Levine, M.; Chen, K. Comprehensive single-cell transcriptome lineages of a proto-vertebrate. Nature 2019, 571, 349-354. [CrossRef]

28. José-Edwards, D.S.; Oda-Ishii, I.; Kugler, J.E.; Passamaneck, Y.J.; Katikala, L.; Nibu, Y.; Di Gregorio, A. Brachyury, Foxa2 and the cis-Regulatory Origins of the Notochord. PLoS Genet. 2015, 11, e1005730. [CrossRef]

29. Moret, F.; Christiaen, L.; Deyts, C.; Blin, M.; Joly, J.S.; Vernier, P. The dopamine-synthesizing cells in the swimming larva of the tunicate Ciona intestinalis are located only in the hypothalamus-related domain of the sensory vesicle. Eur. J. Neurosci. 2005, 21, 3043-3055. [CrossRef]

30. Moret, F.; Christiaen, L.; Deyts, C.; Blin, M.; Vernier, P.; Joly, J.S. Regulatory gene expressions in the ascidian ventral sensory vesicle: Evolutionary relationships with the vertebrate hypothalamus. Dev. Biol. 2005, 277, 567-579. [CrossRef]

31. Sharma, S.; Wang, W.; Stolfi, A. Single-cell transcriptome profiling of the Ciona larval brain. Dev. Biol. 2019, 448, 226-236. [CrossRef]

32. Albert, N.W.; Davies, K.M.; Schwinn, K.E. Gene regulation networks generate diverse pigmentation patterns in plants. Plant Signal. Behav. 2014, 9, e29526. [CrossRef] [PubMed]

33. Gao, F.; Robe, K.; Gaymard, F.; Izquierdo, E.; Dubos, C. The Transcriptional Control of Iron Homeostasis in Plants: A Tale of bHLH Transcription Factors? Front. Plant Sci. 2019, 10, 6. [CrossRef] [PubMed]

34. Kewley, R.J.; Whitelaw, M.L.; Chapman-Smith, A. The mammalian basic helix-loop-helix/PAS family of transcriptional regulators. Int. J. Biochem. Cell Biol. 2004, 36, 189-204. [CrossRef]

35. Richards, G.S.; Simionato, E.; Perron, M.; Adamska, M.; Vervoort, M.; Degnan, B.M. Sponge Genes Provide New Insight into the Evolutionary Origin of the Neurogenic Circuit. Curr. Biol. 2008, 18, 1156-1161. [CrossRef]

36. Simionato, E.; Ledent, V.; Richards, G.; Thomas-Chollier, M.; Kerner, P.; Coornaert, D.; Degnan, B.M.; Vervoort, M. Origin and diversification of the basic helix-loop-helix gene family in metazoans: Insights from comparative genomics. BMC Evol. Biol. 2007, 7, 33. [CrossRef]

37. Gyoja, F. Basic helix-loop-helix transcription factors in evolution: Roles in development of mesoderm and neural tissues. Genesis 2017, 55. [CrossRef]

38. Berkes, C.A.; Tapscott, S.J. MyoD and the transcriptional control of myogenesis. Semin. Cell Dev. Biol. 2005, 16, 585-595. [CrossRef]

39. Bertrand, N.; Castro, D.S.; Guillemot, F. Proneural genes and the specification of neural cell types. Nat. Rev. Neurosci. 2002, 3, 517-530. [CrossRef]

40. Dennis, D.J.; Han, S.; Schuurmans, C. bHLH transcription factors in neural development, disease, and reprogramming. Brain Res. 2019, 1705, 48-65. [CrossRef]

41. Fu, Y.; Yuan, S.-S.; Zhang, L.-J.; Ji, Z.-L.; Quan, X.-J. Atonal bHLH transcription factor 1 is an important factor for maintaining the balance of cell proliferation and differentiation in tumorigenesis. Oncol. Lett. 2020, 20, 2595-2605. [CrossRef]

42. Zhu, Q.Q.; Ma, C.; Wang, Q.; Song, Y.; Lv, T. The role of TWIST1 in epithelial-mesenchymal transition and cancers. Tumor Biol. 2016, 37, 185-197. [CrossRef] [PubMed]

43. Takada, H.; Hattori, D.; Kitayama, A.; Ueno, N.; Taira, M. Identification of target genes for the Xenopus Hes-related protein XHR1, a prepattern factor specifying the midbrain-hindbrain boundary. Dev. Biol. 2005, 283, 253-267. [CrossRef] [PubMed]

44. Vue, T.Y.; Aaker, J.; Taniguchi, A.; Kazemzadeh, C.; Skidmore, J.M.; Martin, D.M.; Martin, J.F.; Treier, M.; Nakagawa, Y. Characterization of progenitor domains in the developing mouse thalamus. J. Comp. Neurol. 2007, 505, 73-91. [CrossRef] [PubMed]

45. Huang, C.; Chan, J.A.; Schuurmans, C. Proneural bHLH Genes in Development and Disease. Curr. Top. Dev. Biol. 2014, 110, 75-127. [CrossRef]

46. Corbo, J.C.; Di Gregorio, A.; Levine, M. The ascidian as a model organism in developmental and evolutionary biology. Cell 2001. [CrossRef]

47. Passamaneck, Y.J.; Di Gregorio, A. Ciona ntestinalis: Chordate development made simple. Dev. Dyn. 2005, 233, 1-19. [CrossRef]

48. Ryan, K.; Lu, Z.; Meinertzhagen, I.A. The CNS connectome of a tadpole larva of Ciona intestinalis (L.) highlights sidedness in the brain of a chordate sibling. ELife 2016, 5, e16962. [CrossRef]

49. Di Gregorio, A.; Corbo, J.C.; Levine, M. The Regulation of forkhead/HNF-3 $\beta$ Expression in the Ciona Embryo. Dev. Biol. 2001, 229, 31-43. [CrossRef] 
50. Imai, K.S.; Hino, K.; Yagi, K.; Satoh, N.; Satou, Y. Gene expression profiles of transcription factors and signaling molecules in the ascidian embryo: Towards a comprehensive understanding of gene networks. Development 2004, 131, 4047-4058. [CrossRef]

51. José-Edwards, D.S.; Kerner, P.; Kugler, J.E.; Deng, W.; Jiang, D.; Di Gregorio, A. The identification of transcription factors expressed in the notochord of Ciona intestinalis adds new potential players to the brachyury gene regulatory network. Dev. Dyn. 2011, 240, 1793-1805. [CrossRef]

52. Yasuo, H.; Satoh, N. Function of vertebrate T gene. Nature 1993, 364, 582-583. [CrossRef] [PubMed]

53. Ikuta, T.; Yoshida, N.; Satoh, N.; Saiga, H. Ciona ntestinalis Hox gene cluster: Its dispersed structure and residual colinear expression in development. Proc. Natl. Acad. Sci. USA 2004, 101, 15118-15123. [CrossRef] [PubMed]

54. Keys, D.N.; Lee, B.I.; Di Gregorio, A.; Harafuji, N.; Detter, J.C.; Wang, M.; Kahsai, O.; Ahn, S.; Zhang, C.; Doyle, S.A.; et al. A saturation screen for cis-acting regulatory DNA in the Hox genes of Ciona intestinalis. Proc. Natl. Acad. Sci. USA 2005, 102, 679-683. [CrossRef] [PubMed]

55. Albuixech-Crespo, B.; Blanch, L.L.; Burguera, D.; Maeso, I.; Sánchez-Arrones, L.; A Moreno-Bravo, J.; Somorjai, I.M.; Pascual-Anaya, J.; Puelles, E.; Bovolenta, P.; et al. Molecular regionalization of the developing amphioxus neural tube challenges major partitions of the vertebrate brain. PLoS Biol. 2017, 15, e2001573. [CrossRef] [PubMed]

56. Puelles, L.; Rubenstein, J.L. Expression patterns of homeobox and other putative regulatory genes in the embryonic mouse forebrain suggest a neuromeric organization. Trends Neurosci. 1993, 16, 472-479. [CrossRef]

57. Vieira, C.; Pombero, A.; Garcia-Lopez, R.; Gimeno, L.; Echevarria, D.; Martinez, S. Molecular mechanisms controlling brain development: An overview of neuroepithelial secondary organizers. Int. J. Dev. Biol. 2010, 54, 7-20. [CrossRef]

58. Anderson, C.; Stern, C.D. Organizers in Development. Curr. Top. Dev. Biol. 2016, 117, 435-454. [CrossRef]

59. Martinez Arias, A.; Steventon, B. On the nature and function of organizers. Development 2018, 145, dev159525. [CrossRef]

60. Pani, A.M.; Mullarkey, E.E.; Aronowicz, J.; Assimacopoulos, S.; Grove, E.A.; Lowe, C.J. Ancient deuterostome origins of vertebrate brain signalling centres. Nature 2012, 483, 289-294. [CrossRef]

61. Takahashi, T.; Holland, P.W. Amphioxus and ascidian Dmbx homeobox genes give clues to the vertebrateorigins of midbrain development. Development 2004, 131, 3285-3294. [CrossRef]

62. Ikuta, T.; Saiga, H. Dynamic change in the expression of developmental genes in the ascidian central nervous system: Revisit to the tripartite model and the origin of the midbrain-hindbrain boundary region. Dev. Biol. 2007, 312, 631-643. [CrossRef] [PubMed]

63. Imai, K.S.; Stolfi, A.; Levine, M.; Satou, Y. Gene regulatory networks underlying the compartmentalization of the Ciona central nervous system. Development 2009, 136, 285-293. [CrossRef] [PubMed]

64. Rubenstein, J.L.; Shimamura, K.; Martinez, S.; Puelles, L. Regionalization of the prosencephalic neural plate. Ann. Rev. Neurosci. 1998, 21, 445-477. [CrossRef] [PubMed]

65. Dickmeis, T.; Rastegar, S.; Lam, C.S.; Aanstad, P.; Clark, M.; Fischer, N.; Rosa, F.; Korzh, V.; Strähle, U. Expression of the helix-loop-helix gene id3 in the zebrafish embryo. Mech. Dev. 2002, 113, 99-102. [CrossRef]

66. Ross, S.E.; Greenberg, M.E.; Stiles, C.D. Basic Helix-Loop-Helix Factors in Cortical Development. Neuron 2003, 39, 13-25. [CrossRef]

67. Moret, F.; Guilland, J.C.; Coudouel, S.; Rochette, L.; Vernier, P. Distribution of tyrosine hydroxylase, dopamine, and serotonin in the central nervous system of amphioxus (Branchiostoma lanceolatum): Implications for the evolution of catecholamine systems in vertebrates. J. Comp. Neurol. 2004, 468, 135-150. [CrossRef]

68. Manni, L.; Agnoletto, A.; Zaniolo, G.; Burighel, P. Stomodeal and neurohypophysial placodes inCiona Intestinalis: Insights into the origin of the pituitary gland. J. Exp. Zoöl. B Mol. Dev. Evol. 2005, 304, 324-339. [CrossRef]

69. Christiaen, L.; Jaszczyszyn, Y.; Kerfant, M.; Kano, S.; Thermes, V.; Joly, J.-S. Evolutionary modification of mouth position in deuterostomes. Semin. Cell Dev. Biol. 2007, 18, 502-511. [CrossRef]

70. Veeman, M.T.; Newman-Smith, E.; El-Nachef, D.; Smith, W.C. The ascidian mouth opening is derived from the anterior neuropore: Reassessing the mouth/neural tube relationship in chordate evolution. Dev. Biol. 2010, 344, 138-149. [CrossRef] 
71. Glardon, S.; Holland, L.Z.; Gehring, W.J.; Holland, N.D. Isolation and developmental expression of the amphioxus Pax-6 gene (AmphiPax-6): Insights into eye and photoreceptor evolution. Development 1998, 125, 2701-2710. [PubMed]

72. Candiani, S.; Holland, N.D.; Oliveri, D.; Parodi, M.; Pestarino, M. Expression of the amphioxus Pit-1 gene (AmphiPOU1F1/Pit-1) exclusively in the developing preoral organ, a putative homolog of the vertebrate adenohypophysis. Brain Res. Bull. 2008, 75, 324-330. [CrossRef] [PubMed]

73. Candiani, S.; Pestarino, M. Evidence for the presence of the tissue-specific transcription factor Pit-1 in lancelet larvae. J. Comp. Neurol. 1998, 400, 310-316. [CrossRef]

74. Li, G.; Liu, X.; Xing, C.; Zhang, H.; Shimeld, S.M.; Wang, Y. Cerberus-Nodal-Lefty-Pitx signaling cascade controls left-right asymmetry in amphioxus. Proc. Natl. Acad. Sci. USA 2017, 114, 3684-3689. [CrossRef] [PubMed]

75. Kano, S. Genomics and Developmental Approaches to an Ascidian Adenohypophysis Primordium. Integr. Comp. Biol. 2010, 50, 35-52. [CrossRef]

76. Christiaen, L.; Burighel, P.; Smith, W.C.; Vernier, P.; Bourrat, F.; Joly, J.-S. Pitx genes in Tunicates provide new molecular insight into the evolutionary origin of pituitary. Gene 2002, 287, 107-113. [CrossRef]

77. Christiaen, L.; Bourrat, F.; Joly, J.-S. A modular cis-regulatory system controls isoform-specific pitx expression in ascidian stomodæum. Dev. Biol. 2005, 277, 557-566. [CrossRef]

78. Di Fiore, M.M.; Rastogi, R.K.; Ceciliani, F.; Messi, E.; Botte, V.; Botte, L.; Pinelli, C.; D'Aniello, B.; D'Aniello, A. Mammalian and chicken I forms of gonadotropin-releasing hormone in the gonads of a protochordate, Ciona ntestinalis. Proc. Natl. Acad. Sci. USA 2000, 97, 2343-2348. [CrossRef]

79. Manni, L.; Lane, N.J.; Burighel, P.; Zaniolo, G. Are neural crest and placodes exclusive to vertebrates? Evol. Dev. 2001, 3, 297-298. [CrossRef]

80. Pestarino, M. Immunocytochemical demonstration of prolactin-like activity in the neural gland of the ascidian Styela plicata. Gen. Comp. Endocrinol. 1984, 54, 444-449. [CrossRef]

81. Boorman, C.J.; Shimeld, S.M. The evolution of left-right asymmetry in chordates. BioEssays 2002, 24, 1004-1011. [CrossRef]

82. Poulin, G.; Lebel, M.; Chamberland, M.; Paradis, F.W.; Drouin, J.; Hall, C.; Nelson, D.M.; Ye, X.; Baker, K.; DeCaprio, J.A.; et al. Specific Protein-Protein Interaction between Basic Helix-Loop-Helix Transcription Factors and Homeoproteins of the Pitx Family. Mol. Cell. Biol. 2000, 20, 4826-4837. [CrossRef] [PubMed]

83. Ando, M.; Goto, M.; Hojo, M.; Kita, A.; Kitagawa, M.; Ohtsuka, T.; Kageyama, R.; Miyamoto, S. The proneural bHLH genes Mash1, Math3 and NeuroD are required for pituitary development. J. Mol. Endocrinol. 2018, 61, 127-138. [CrossRef]

84. Joyce Tang, W.; Chen, J.S.; Zeller, R.W. Transcriptional regulation of the peripheral nervous system in Ciona intestinalis. Dev. Biol. 2013, 378, 183-193. [CrossRef]

85. Osugi, T.; Sasakura, Y.; Esatake, H. The nervous system of the adult ascidian Ciona intestinalis Type A (Ciona robusta): Insights from transgenic animal models. PLoS ONE 2017, 12, e0180227. [CrossRef] [PubMed]

86. Ryan, K.; Meinertzhagen, I.A. Neuronal identity: The neuron types of a simple chordate sibling, the tadpole larva of Ciona intestinalis. Curr. Opin. Neurobiol. 2019, 56, 47-60. [CrossRef] [PubMed]

87. Halluin, C.; Madelaine, R.; Naye, F.; Peers, B.; Roussigné, M.; Blader, P. Habenular Neurogenesis in Zebrafish Is Regulated by a Hedgehog, Pax6 Proneural Gene Cascade. PLoS ONE 2016, 11, e0158210. [CrossRef] [PubMed]

88. Muñoz, E.M.; Bailey, M.J.; Rath, M.F.; Shi, Q.; Morin, F.; Coon, S.L.; Møller, M.; Klein, D.C. NeuroD1: Developmental expression and regulated genes in the rodent pineal gland. J. Neurochem. 2007, 102, 887-899. [CrossRef] [PubMed]

89. Lacalli, T. Amphioxus, motion detection, and the evolutionary origin of the vertebrate retinotectal map. EvoDevo 2018, 9, 6. [CrossRef]

90. Pergner, J.; Kozmik, Z. Amphioxus photoreceptors-Insights into the evolution of vertebrate opsins, vision and circadian rhythmicity. Int. J. Dev. Biol. 2017, 61, 665-681. [CrossRef]

91. Cau, E.; Wilson, S.W. Ash1a and Neurogenin1 function downstream of Floating head to regulate epiphysial neurogenesis. Development 2003, 130, 2455-2466. [CrossRef]

92. Utsumi, N.; Shimojima, Y.; Saiga, H. Analysis of ascidian Not genes highlights their evolutionarily conserved and derived features of structure and expression in development. Dev. Genes Evol. 2004, 214, 460-465. [CrossRef] [PubMed] 
93. Kusakabe, T.; Tsuda, M. Photoreceptive Systems in Ascidians. Photochem. Photobiol. 2007, 83, $248-252$. [CrossRef]

94. Jamieson, D.; Roberts, A. Responses of young Xenopus laevis tadpoles to light dimming: Possible roles for the pineal eye. J. Exp. Biol. 2000, 203 Pt 12, 1857-1867. [PubMed]

95. Kako, K.; Ishida, N. The role of transcription factors in circadian gene expression. Neurosci. Res. 1998, 31, 257-264. [CrossRef]

96. Minamoto, T.; Hanai, S.; Kadota, K.; Oishi, K.; Matsumae, H.; Fujie, M.; Azumi, K.; Satoh, N.; Satake, M.; Ishida, N. Circadian clock in Ciona intestinalis revealed by microarray analysis and oxygen consumption. J. Biochem. 2010, 147, 175-184. [CrossRef]

97. Zega, G.; Biggiogero, M.; Groppelli, S.; Candiani, S.; Oliveri, D.; Parodi, M.; Pestarino, M.; De Bernardi, F.; Pennati, R. Developmental expression ofglutamic acid decarboxylaseand of $\gamma$-aminobutyricacid type B receptors in the ascidian Ciona intestinalis. J. Comp. Neurol. 2008, 506, 489-505. [CrossRef] [PubMed]

98. Rudolf, J.; Dondorp, D.; Canon, L.; Tieo, S.; Chatzigeorgiou, M. Automated behavioural analysis reveals the basic behavioural repertoire of the urochordate Ciona intestinalis. Sci. Rep. 2019, 9, 2416. [CrossRef] [PubMed]

99. Nakagawa, M.; Miyamoto, T.; Ohkuma, M.; Tsuda, M. Action spectrum for the photophobic response of Ciona intestinalis (Ascidieacea, Urochordata) larvae implicates retinal protein. Photochem. Photobiol. 1999, 70, 359-362. [CrossRef] [PubMed]

100. Kawakami, I.; Shiraishi, S.; Tsuda, M. Photoresponse and Learning Behavior of Ascidian Larvae, a Primitive Chordate, to Repeated Stimuli of Step-Up and Step-Down of Light. J. Biol. Phys. 2002, 28, 549-559. [CrossRef] [PubMed]

101. Tsuda, M.; Kusakabe, T.; Iwamoto, H.; Horie, T.; Nakashima, Y.; Nakagawa, M.; Okunou, K. Origin of the vertebrate visual cycle: II. Visual cycle proteins are localized in whole brain including photoreceptor cells of a primitive chordate. Vis. Res. 2003, 43, 3045-3053. [CrossRef]

102. Bostwick, M.; Smith, E.L.; Borba, C.; Newman-Smith, E.; Guleria, I.; Kourakis, M.J.; Smith, W.C. Antagonistic Inhibitory Circuits Integrate Visual and Gravitactic Behaviors. Curr. Biol. 2020, 30, 600-609. [CrossRef] [PubMed]

103. Kratsios, P.; Stolfi, A.; Levine, M.; Hobert, O. Coordinated regulation of cholinergic motor neuron traits through a conserved terminal selector gene. Nat. Neurosci. 2011, 15, 205-214. [CrossRef] [PubMed]

104. Lemaire, P.; Bertrand, V.; Hudson, C. Early steps in the formation of neural tissue in ascidian embryos. Dev. Biol. 2002, 252, 151-169. [CrossRef] [PubMed]

105. Stolfi, A.; Ryan, K.; Meinertzhagen, I.A.; Christiaen, L. Migratory neuronal progenitors arise from the neural plate borders in tunicates. Nat. Cell Biol. 2015, 527, 371-374. [CrossRef] [PubMed]

106. Imai, J.H.; Meinertzhagen, I.A. Neurons of the ascidian larval nervous system in Ciona intestinalis: I. Central nervous system. J. Comp. Neurol. 2007, 501, 316-334. [CrossRef]

107. Ryan, K.; Lu, Z.; Meinertzhagen, I.A. The peripheral nervous system of the ascidian tadpole larva: Types of neurons and their synaptic networks. J. Comp. Neurol. 2018, 526, 583-608. [CrossRef]

108. Kim, K.; Gibboney, S.; Razy-Krajka, F.; Lowe, E.K.; Wang, W.; Stolfi, A. Regulation of Neurogenesis by FGF Signaling and Neurogenin in the Invertebrate Chordate Ciona. Front. Cell Dev. Biol. 2020, 8, 477. [CrossRef]

109. Horie, T.; Nakagawa, M.; Sasakura, Y.; Kusakabe, T. Cell type and function of neurons in the ascidian nervous system. Dev. Growth Differ. 2009, 51, 207-220. [CrossRef]

110. Sorrentino, M.; Manni, L.; Lane, N.J.; Burighel, P. Evolution of cerebral vesicles and their sensory organs in an ascidian larva. Acta Zool. 2001, 81, 243-258. [CrossRef]

111. Dilly, P.N. Studies on the receptors in the cerebral vesicle of the ascidian tadpole. 1. The Otolith. Q. J. Microsc. Sci. 1964, 103, 393-398.

112. Hudson, C. The central nervous system of ascidian larvae. Wiley Interdiscip. Rev. Dev. Biol. 2016, 5, 538-561. [CrossRef] [PubMed]

113. Dilly, P.N. Studies on the receptors in the cerebral vesicle of the ascidian tadpole. 2. The Ocellus. Q. J. Microsc. Sci. 1964, 105, 13-20.

114. Horie, T.; Sakurai, D.; Ohtsuki, H.; Terakita, A.; Shichida, Y.; Usukura, J.; Kusakabe, T.; Tsuda, M. Pigmented and nonpigmented ocelli in the brain vesicle of the ascidian larva. J. Comp. Neurol. 2008, 509, 88-102. [CrossRef] 
115. Oonuma, K.; Tanaka, M.; Nishitsuji, K.; Kato, Y.; Shimai, K.; Kusakabe, T.G. Revised lineage of larval photoreceptor cells in Ciona reveals archetypal collaboration between neural tube and neural crest in sensory organ formation. Dev. Biol. 2016, 420, 178-185. [CrossRef]

116. D'Aniello, S.; D'Aniello, E.; Locascio, A.; Memoli, A.; Corrado, M.; Russo, M.T.; Aniello, F.; Fucci, L.; Brown, E.R.; Branno, M. The ascidian homolog of the vertebrate homeobox gene Rx is essential for ocellus development and function. Differentiation 2006, 74, 222-234. [CrossRef] [PubMed]

117. Oonuma, K.; Kusakabe, T.G. Spatio-temporal regulation of Rx and mitotic patterns shape the eye-cup of the photoreceptor cells in Ciona. Dev. Biol. 2019, 445, 245-255. [CrossRef]

118. Hodgkinson, C.A.; Moore, K.J.; Nakayama, A.; Steingrimsson, E.; Copeland, N.G.; Jenkins, N.A.; Arnheiter, H. Mutations at the mouse microphthalmia locus are associated with defects in a gene encoding a novel basic-helix-loop-helix-zipper protein. Cell 1993, 74, 395-404. [CrossRef]

119. Yajima, I.; Endo, K.; Sato, S.; Toyoda, R.; Wada, H.; Shibahara, S.; Numakunai, T.; Ikeo, K.; Gojobori, T.; Goding, C.R.; et al. Cloning and functional analysis of ascidian Mitf in vivo: Insights into the origin of vertebrate pigment cells. Mech. Dev. 2003, 120, 1489-1504. [CrossRef]

120. Abitua, P.B.; Wagner, E.; Navarrete, I.A.; Levine, M. Identification of a rudimentary neural crest in a non-vertebrate chordate. Nature 2012, 492, 104-107. [CrossRef]

121. Curran, K.; Lister, J.A.; Kunkel, G.R.; Prendergast, A.; Parichy, D.M.; Raible, D.W. Interplay between Foxd3 and Mitf regulates cell fate plasticity in the zebrafish neural crest. Dev. Biol. 2010, 344, 107-118. [CrossRef]

122. Soo, K.; O'Rourke, M.P.; Khooa, P.L.; Steiner, K.A.; Wonga, N.; Behringer, R.R.; Tam, P.P. Twist Function Is Required for the Morphogenesis of the Cephalic Neural Tube and the Differentiation of the Cranial Neural Crest Cells in the Mouse Embryo. Dev. Biol. 2002, 247, 251-270. [CrossRef] [PubMed]

123. VanDusen, N.J.; Firulli, A.B. Twist factor regulation of non-cardiomyocyte cell lineages in the developing heart. Differentiation 2012, 84, 79-88. [CrossRef] [PubMed]

124. Tokuoka, M.; Imai, K.S.; Satou, Y.; Satoh, N. Three distinct lineages of mesenchymal cells in Ciona intestinalis embryos demonstrated by specific gene expression. Dev. Biol. 2004, 274, 211-224. [CrossRef] [PubMed]

125. Nishida, H.; Satoh, N. Determination and regulation in the pigment cell lineage of the ascidian embryo. Dev. Biol. 1989, 132, 355-367. [CrossRef]

126. Razy-Krajka, F.; Brown, E.R.; Horie, T.; Callebert, J.; Sasakura, Y.; Joly, J.S.; Kusakabe, T.G.; Vernier, P. Monoaminergic modulation of photoreception in ascidian: Evidence for a proto-hypothalamo-retinal territory. BMC Biol. 2012, 10, 45. [CrossRef]

127. Yoshida, K.; Saiga, H. Repression of Rx gene on the left side of the sensory vesicle by Nodal signaling is crucial for right-sided formation of the ocellus photoreceptor in the development of Ciona intestinalis. Dev. Biol. 2011, 354, 144-150. [CrossRef]

128. Takamura, K.; Minamida, N.; Okabe, S. Neural Map of the Larval Central Nervous System in the Ascidian Ciona intestinalis. Zool. Sci. 2010, 27, 191-203; PMID: 20141424. [CrossRef]

129. Sasakura, Y.; Hozumi, A. Formation of adult organs through metamorphosis in ascidians. Wiley Interdiscip. Rev. Dev. Biol. 2017, 7. [CrossRef]

130. Satoh, N. An Advanced Filter-Feeder Hypothesis for Urochordate Evolution. Zool. Sci. 2009, 26, 97-111. [CrossRef]

131. Horie, T.; Shinki, R.; Ogura, Y.; Kusakabe, T.; Satoh, N.; Sasakura, Y. Ependymal cells of chordate larvae are stem-like cells that form the adult nervous system. Nature 2011, 469, 525-528. [CrossRef]

132. Lambert, C.C.; Brandt, C.L. The Effect of Light on the Spawning of Ciona Intestinalis. Biol. Bull. 1967, 132, 222-228. [CrossRef] [PubMed]

133. Auger, H.; Sasakura, Y.; Joly, J.-S.; Jeffery, W.R. Regeneration of oral siphon pigment organs in the ascidian Ciona intestinalis. Dev. Biol. 2010, 339, 374-389. [CrossRef] [PubMed]

134. Ohkuma, M.; Katagiri, Y.; Nakagawa, M.; Tsuda, M. Possible involvement of light regulated gonadotropinreleasing hormone neurons in biological clock for reproduction in the cerebral ganglion of the ascidian, Halocynthia roretzi. Neurosci. Lett. 2000, 293, 5-8. [CrossRef]

135. Tsutsui, H.; Oka, Y. Light-sensitive voltage responses in the neurons of the cerebral ganglion of Ciona savignyi (Chordata: Ascidiacea). Biol. Bull. 2000, 198, 26-28. [CrossRef]

136. Ogasawara, M.; Sasaki, A.; Metoki, H.; Shin-I, T.; Kohara, Y.; Satoh, N.; Satou, Y. Gene expression profiles in young adult Ciona intestinalis. Dev. Genes Evol. 2002, 212, 173-185. [CrossRef] [PubMed] 
137. Hamada, M.; Gorički, Š.; Byerly, M.S.; Satoh, N.; Jeffery, W.R. Evolution of the chordate regeneration blastema: Differential gene expression and conserved role of notch signaling during siphon regeneration in the ascidian Ciona. Dev. Biol. 2015, 405, 304-315. [CrossRef]

138. Pennati, R.; Ficetola, G.F.; Brunetti, R.; Caicci, F.; Gasparini, F.; Griggio, F.; Sato, A.; Stach, T.; Kaul-Strehlow, S.; Gissi, C.; et al. Morphological Differences between Larvae of the Ciona intestinalis Species Complex: Hints for a Valid Taxonomic Definition of Distinct Species. PLoS ONE 2015, 10, e0122879. [CrossRef]

139. Dehal, P.; Satou, Y.; Campbell, R.K.; Chapman, J.; Degnan, B.; De Tomaso, A.; Davidson, B.; Di Gregorio, A.; Gelpke, M.; Goodstein, D.M.; et al. The Draft Genome of Ciona intestinalis: Insights into Chordate and Vertebrate Origins. Science 2002, 298, 2157-2167. [CrossRef]

140. Satou, Y.; Nakamura, R.; Yu, D.; Yoshida, R.; Hamada, M.; Fujie, M.; Hisata, K.; Takeda, H.; Satoh, N.; Nakmura, R.; et al. A Nearly Complete Genome of Ciona intestinalis Type A (C. robusta) Reveals the Contribution of Inversion to Chromosomal Evolution in the Genus Ciona. Genome Biol. Evol. 2019, 11, 3144-3157. [CrossRef]

141. Kusakabe, T.; Yoshida, R.; Kawakami, I.; Kusakabe, R.; Mochizuki, Y.; Yamada, L.; Shin-I, T.; Kohara, Y.; Satoh, N.; Tsuda, M.; et al. Gene Expression Profiles in Tadpole Larvae of Ciona intestinalis. Dev. Biol. 2002, 242, 188-203. [CrossRef]

142. Fujiwara, S.; Maeda, Y.; Shin-I, T.; Kohara, Y.; Takatori, N.; Satou, Y.; Satoh, N. Gene expression profiles in Ciona intestinalis cleavage-stage embryos. Mech. Dev. 2002, 112, 115-127. [CrossRef]

143. Miwata, K.; Chiba, T.; Horii, R.; Yamada, L.; Kubo, A.; Miyamura, D.; Satoh, N.; Satou, Y. Systematic analysis of embryonic expression profiles of zinc finger genes in Ciona intestinalis. Dev. Biol. 2006, 292, 546-554. [CrossRef]

144. Yamada, L.; Shoguchi, E.; Wada, S.; Kobayashi, K.; Mochizuki, Y.; Satou, Y.; Satoh, N. Morpholino-based gene knockdown screen of novel genes with developmental function in Ciona intestinalis. Development 2003, 130, 6485-6495. [CrossRef] [PubMed]

145. Hamada, M.; Wada, S.; Kobayashi, K.; Satoh, N. Novel genes involved in Ciona intestinalis embryogenesis: Characterization of gene knockdown embryos. Dev. Dyn. 2007, 236, 1820-1831. [CrossRef] [PubMed]

146. Nitta, K.R.; Vincentelli, R.; Jacox, E.; Cimino, A.; Ohtsuka, Y.; Sobral, D.; Satou, Y.; Cambillau, C.; Lemaire, P. High-Throughput Protein Production Combined with High- Throughput SELEX Identifies an Extensive Atlas of Ciona robusta Transcription Factor DNA-Binding Specificities. Methods Mol. Biol. 2019, 2025, 487-517. [CrossRef] [PubMed]

147. Satou, Y.; Imai, K.S.; Levine, M.; Kohara, Y.; Rokhsar, D.; Satoh, N. A genomewide survey of developmentally relevant genes in Ciona intestinalis. Dev. Genes Evol. 2003, 213, 213-221. [CrossRef] [PubMed]

148. Jones, S. An overview of the basic helix-loop-helix proteins. Genome Biol. 2004, 5, 226. [CrossRef]

149. Menon, S.; Lawrence, C. Helix-Turn-Helix Motif. In Brenner's Encyclopedia of Genetics, 2nd ed.; Elsevier BV: Amsterdam, The Netherlands, 2013; pp. 412-415.

150. Murre, C. Helix-loop-helix proteins and the advent of cellular diversity: 30 years of discovery. Genes Dev. 2019, 33, 6-25. [CrossRef]

151. Ledent, V.; Vervoort, M. The Basic Helix-Loop-Helix Protein Family: Comparative Genomics and Phylogenetic Analysis. Genome Res. 2001, 11, 754-770. [CrossRef] [PubMed]

152. Suzuki, M.; Sato, F.; Bhawal, U.K. The basic helix-loop-helix (bHLH) transcription factor DEC2 negatively regulates Twist1 through an E-box element. Biochem. Biophys. Res. Commun. 2014, 455, 390-395. [CrossRef]

153. Di Gregorio, A.; Spagnuolo, A.; Ristoratore, F.; Pischetola, M.; Aniello, F.; Branno, M.; Cariello, L.; Di Lauro, R. Cloning of ascidian homeobox genes provides evidence for a primordial chordate cluster. Gene 1995, 156, 253-257. [CrossRef]

154. Wada, S.; Tokuoka, M.; Shoguchi, E.; Kobayashi, K.; Di Gregorio, A.; Spagnuolo, A.; Branno, M.; Kohara, Y.; Rokhsar, D.S.; Levine, M.; et al. A genomewide survey of developmentally relevant genes in Ciona intestinalis. Dev. Genes Evol. 2003, 213, 222-234. [CrossRef] [PubMed]

155. Di Gregorio, A. T-Box Genes and Developmental Gene Regulatory Networks in Ascidians. Curr. Top. Dev. Biol. 2017, 122, 55-91. [CrossRef]

156. Meedel, T.H.; Farmer, S.C.; Lee, J.J. The single MyoD family gene of Ciona intestinalis encodes two differentially expressed proteins: Implications for the evolution of chordate muscle gene regulation. Development 1997, 124, 1711-1721. [PubMed] 
157. Ratcliffe, L.E.; Asiedu, E.K.; Pickett, C.J.; Warburton, M.A.; Izzi, S.A.; Meedel, T.H. The Ciona myogenic regulatory factor functions as a typical MRF but possesses a novel $\mathrm{N}$-terminus that is essential for activity. Dev. Biol. 2019, 448, 210-225. [CrossRef]

158. Aase-Remedios, M.E.; Coll-Lladó, C.; Ferrier, D.E.K. More than one-to-four via 2R: Evidence of an independent amphioxus expansion and two-gene ancestral vertebrate state for MyoD-related Muscle Regulatory Factors (MRFs). Mol. Biol. Evol. 2020, 147. [CrossRef]

159. Davidson, B.; Levine, M. Evolutionary origins of the vertebrate heart: Specification of the cardiac lineage in Ciona intestinalis. Proc. Natl. Acad. Sci. USA 2003, 100, 11469-11473. [CrossRef]

160. Satou, Y.; Imai, K.S.; Satoh, N. The ascidian Mesp gene specifies heart precursor cells. Development 2004, 131, 2533-2541. [CrossRef]

161. Waldrop, L.D.; Miller, L.A. The role of the pericardium in the valveless, tubular heart of the tunicate Ciona savignyi. J. Exp. Biol. 2015, 218 Pt 17, 2753-2763. [CrossRef]

162. Liang, Q.; Xu, C.; Chen, X.; Li, X.; Lu, C.; Zhou, P.; Yin, L.; Qian, R.; Chen, S.; Ling, Z.; et al. The roles of Mesp family proteins: Functional diversity and redundancy in differentiation of pluripotent stem cells and mammalian mesodermal development. Protein Cell 2015, 6, 553-561. [CrossRef] [PubMed]

163. Waki, K.; Imai, K.S.; Satou, Y. Genetic pathways for differentiation of the peripheral nervous system in ascidians. Nat. Commun. 2015, 6, 8719. [CrossRef] [PubMed]

164. Imai, K.S.; Levine, M.; Satoh, N.; Satou, Y. Regulatory Blueprint for a Chordate Embryo. Science 2006, 312, 1183-1187. [CrossRef]

165. Horie, T.; Horie, R.; Chen, K.; Cao, C.; Nakagawa, M.; Kusakabe, T.G.; Satoh, N.; Sasakura, Y.; Levine, M. Regulatory cocktail for dopaminergic neurons in a protovertebrate identified by whole-embryo single-cell transcriptomics. Genes Dev. 2018, 32, 1297-1302. [CrossRef] [PubMed]

166. Kugler, J.E.; Wu, Y.; Katikala, L.; Passamaneck, Y.J.; Addy, J.; Caballero, N.; Oda-Ishii, I.; Maguire, J.E.; Li, R.; Di Gregorio, A. Positioning a multifunctional basic helix-loop-helix transcription factor within the Ciona notochord gene regulatory network. Dev. Biol. 2019, 448, 119-135. [CrossRef] [PubMed]

167. Adell, T.; Gómez-Cuadrado, A.; Skoudy, A.; Pettengill, O.S.; Longnecker, D.S.; Real, F.X. Role of the basic helix-loop-helix transcription factor p48 in the differentiation phenotype of exocrine pancreas cancer cells. Cell Growth Differ. 2000, 11, 137-147. [PubMed]

168. Fujitani, Y.; Fujitani, S.; Luo, H.; Qiu, F.; Burlison, J.; Long, Q.; Kawaguchi, Y.; Edlund, H.; Macdonald, R.J.; Furukawa, T.; et al. Ptf1a determines horizontal and amacrine cell fates during mouse retinal development. Development 2006, 133, 4439-4450. [CrossRef] [PubMed]

169. Hoshino, M.; Nakamura, S.; Mori, K.; Kawauchi, T.; Terao, M.; Nishimura, Y.V.; Fukuda, A.; Fuse, T.; Matsuo, N.; Sone, M.; et al. Ptf1a, a bHLH Transcriptional Gene, Defines GABAergic Neuronal Fates in Cerebellum. Neuron 2005, 47, 201-213. [CrossRef] [PubMed]

170. Burlison, J.S.; Long, Q.-M.; Fujitani, Y.; Wright, C.V.; Magnuson, M.A. Pdx-1 and Ptf1a concurrently determine fate specification of pancreatic multipotent progenitor cells. Dev. Biol. 2008, 316, 74-86. [CrossRef]

171. Kawaguchi, Y.; Cooper, B.; Gannon, M.; Ray, M.; Macdonald, R.J.; Wright, C.V. The role of the transcriptional regulator Ptf1a in converting intestinal to pancreatic progenitors. Nat. Genet. 2002, 32, 128-134. [CrossRef]

172. Seo, S.; Lim, J.W.; Yellajoshyula, D.; Chang, L.W.; Kroll, K.L. Neurogenin and NeuroD direct transcriptional targets and their regulatory enhancers. EMBO J. 2007, 26, 5093-5108. [CrossRef]

173. Sommer, L.; Ma, Q.; Anderson, D.J. neurogenins, a Novel Family ofatonal-Related bHLH Transcription Factors, Are Putative Mammalian Neuronal Determination Genes That Reveal Progenitor Cell Heterogeneity in the Developing CNS and PNS. Mol. Cell. Neurosci. 1996, 8, 221-241. [CrossRef] [PubMed]

174. Andersson, E.; Jensen, J.B.; Parmar, M.; Guillemot, F.; Björklund, A. Development of the mesencephalic dopaminergic neuron system is compromised in the absence of neurogenin 2. Development 2006, 133, 507-516. [CrossRef] [PubMed]

175. Kele, J.; Simplicio, N.; Ferri, A.L.; Mira, H.; Guillemot, F.; Arenas, E.; Ang, S.L. Neurogenin 2 is required for the development of ventral midbrain dopaminergic neurons. Development 2006, 133, 495-505. [CrossRef] [PubMed]

176. Carroll, P.A.; Freie, B.W.; Mathsyaraja, H.; Eisenman, R.N. The MYC transcription factor network: Balancing metabolism, proliferation and oncogenesis. Front. Med. 2018, 12, 412-425. [CrossRef] [PubMed]

177. Atchley, W.R.; Fitch, W.M. A natural classification of the basic helix-loop-helix class of transcription factors. Proc. Natl. Acad. Sci. USA 1997, 94, 5172-5176. [CrossRef] 
178. Coppola, U.; Kamal, A.K.; Stolfi, A.; Ristoratore, F. The Cis-Regulatory Code for Kelch-like 21/30 Specific Expression in Ciona robusta Sensory Organs. Front. Collect. 2020, 8. [CrossRef]

179. Hotta, K.; Takahashi, H.; Asakura, T.; Saitoh, B.; Takatori, N.; Satou, Y.; Satoh, N. Characterization of Brachyury-Downstream Notochord Genes in the Ciona intestinalis Embryo. Dev. Biol. 2000, 224, 69-80. [CrossRef]

180. Hotta, K.; Takahashi, H.; Satoh, N.; Gojobori, T. Brachyury-downstream gene sets in a chordate, Ciona ntestinalis: Integrating notochord specification, morphogenesis and chordate evolution. Evol. Dev. 2008, 10, 37-51. [CrossRef]

181. Soyal, S.M.; Amleh, A.; Dean, J. FIGalpha, a germ cell-specific transcription factor required for ovarian follicle formation. Development 2000, 127, 4645-4654. [PubMed]

182. Pangas, S.A.; Rajkovic, A. Transcriptional regulation of early oogenesis: In search of masters. Hum. Reprod. Update 2006, 12, 65-76. [CrossRef]

183. Furness, S.G.B.; Lees, M.J.; Whitelaw, M.L. The dioxin (aryl hydrocarbon) receptor as a model for adaptive responses of bHLH/PAS transcription factors. FEBS Lett. 2007, 581, 3616-3625. [CrossRef]

184. Taylor, B.L.; Zhulin, I.B. PAS Domains: Internal Sensors of Oxygen, Redox Potential, and Light. Microbiol. Mol. Biol. Rev. 1999, 63, 479-506. [CrossRef]

185. Möglich, A.; Ayers, R.A.; Moffat, K. Structure and Signaling Mechanism of Per-ARNT-Sim Domains. Structure 2009, 17, 1282-1294. [CrossRef] [PubMed]

186. Michaud, J.L.; DeRossi, C.; May, N.R.; Holdener, B.C.; Fan, C.M. ARNT2 acts as the dimerization partner of SIM1 for the development of the hypothalamus. Mech. Dev. 2000, 90, 253-261. [CrossRef]

187. Pasini, A.; Amiel, A.; Rothbächer, U.; Roure, A.; Lemaire, P.; Darras, S. Formation of the ascidian epidermal sensory neurons: Insights into the origin of the chordate peripheral nervous system. PLoS Biol. 2006, 4, e225. [CrossRef]

188. Daburon, V.; Mella, S.; Plouhinec, J.-L.; Mazan, S.; Crozatier, M.; Vincent, A. The metazoan history of the $\mathrm{COE}$ transcription factors. Selection of a variant HLH motif by mandatory inclusion of a duplicated exon in vertebrates. BMC Evol. Biol. 2008, 8, 131. [CrossRef] [PubMed]

189. Razy-Krajka, F.; Lam, K.; Wang, W.; Stolfi, A.; Joly, M.; Bonneau, R.; Christiaen, L. Collier/OLF/EBF-Dependent Transcriptional Dynamics Control Pharyngeal Muscle Specification from Primed Cardiopharyngeal Progenitors. Dev. Cell 2014, 29, 263-276. [CrossRef]

190. Stolfi, A.; Sasakura, Y.; Chalopin, M.; Satou, Y.; Christiaen, L.; Dantec, C.; Endo, T.; Naville, M.; Nishida, H.; Swalla, B.J.; et al. Guidelines for the nomenclature of genetic elements in tunicate genomes. Genesis 2014, 53, 1-14. [CrossRef]

191. Roure, A.; Darras, S. Msxb is a core component of the genetic circuitry specifying the dorsal and ventral neurogenic midlines in the ascidian embryo. Dev. Biol. 2016, 409, 277-287. [CrossRef]

192. Tolkin, T.; Christiaen, L. Rewiring of an ancestral Tbx1/10-Ebf-Mrf network for pharyngeal muscle specification in distinct embryonic lineages. Development 2016, 143, 3852-3862. [CrossRef]

193. Bonfig, W.; Krude, H.; Schmidt, H. A novel mutation of LHX3 is associated with combined pituitary hormone deficiency including ACTH deficiency, sensorineural hearing loss, and short neck-A case report and review of the literature. Eur. J. Pediatr. 2011, 170, 1017-1021. [CrossRef]

194. Carreno, G.; Apps, J.R.; Lodge, E.J.; Panousopoulos, L.; Haston, S.; Gonzalez-Meljem, J.M.; Hahn, H.; Andoniadou, C.L.; Martinez-Barbera, J.P. Hypothalamic sonic hedgehog is required for cell specification and proliferation of LHX3/LHX4 pituitary embryonic precursors. Development 2017, 144, 3289-3302. [CrossRef]

195. Sheng, H.Z.; Moriyama, K.; Yamashita, T.; Li, H.; Potter, S.S.; Mahon, K.A.; Westphal, H. Multistep Control of Pituitary Organogenesis. Science 1997, 278, 1809-1812. [CrossRef] [PubMed]

196. Tsuchida, T.; Ensini, M.; Morton, S.B.; Baldassare, M.; Edlund, T.; Jessell, T.M.; Pfaff, S.L. Topographic organization of embryonic motor neurons defined by expression of LIM homeobox genes. Cell 1994, 79, 957-970. [CrossRef]

197. Stern, J.E. Nitric oxide and homeostatic control: An intercellular signalling molecule contributing to autonomic and neuroendocrine integration? Prog. Biophys. Mol. Biol. 2004, 84, 197-215. [CrossRef] [PubMed]

198. Castellano, I.; Ercolesi, E.; Palumbo, A. Nitric Oxide Affects ERK Signaling through Down-Regulation of MAP Kinase Phosphatase Levels during Larval Development of the Ascidian Ciona intestinalis. PLoS ONE 2014, 9, e102907. [CrossRef] 
199. Ledent, V.; Paquet, O.; Vervoort, M. Phylogenetic analysis of the human basic helix-loop-helix proteins. Genome Biol. 2002, 3. [CrossRef]

200. Patoori, S.; Jean-Charles, N.; Gopal, A.; Sulaiman, S.; Gopal, S.; Wang, B.; Souferi, B.; Emerson, M.M. Cis-regulatory analysis of Onecut1 expression in fate-restricted retinal progenitor cells. Neural Dev. 2020, 15, 1-20. [CrossRef]

201. D'Aniello, E.; Pezzotti, M.R.; Locascio, A.; Branno, M. Onecut is a direct neural-specific transcriptional activator of Rx in Ciona intestinalis. Dev. Biol. 2011, 355, 358-371. [CrossRef]

202. Pezzotti, M.R.; Locascio, A.; Racioppi, C.; Fucci, L.; Branno, M. Auto and cross regulatory elements control Onecut expression in the ascidian nervous system. Dev. Biol. 2014, 390, 273-287. [CrossRef]

203. Song, H.W.; Wilkinson, M.F. Transcriptional control of spermatogonial maintenance and differentiation. Semin. Cell Dev. Biol. 2014, 30, 14-26. [CrossRef]

204. Pangas, S.A.; Choi, Y.; Ballow, D.J.; Zhao, Y.; Westphal, H.; Matzuk, M.M.; Rajkovic, A. Oogenesis requires germ cell-specific transcriptional regulators Sohlh1 and Lhx8. Proc. Natl. Acad. Sci. USA 2006, 103, 8090-8095. [CrossRef] [PubMed]

205. Peter, I.S. Regulatory states in the developmental control of gene expression. Brief. Funct. Genom. 2017, 16, 281-287. [CrossRef]

206. Yan, R.T.; Ma, W.; Liang, L.; Wang, S.Z. bHLH Genes and Retinal Cell Fate Specification. Mol. Neurobiol. 2005, 32, 157-172. [CrossRef]

207. Jahan, I.; Pan, N.; Kersigo, J.; Fritzsch, B. Neurod1 Suppresses Hair Cell Differentiation in Ear Ganglia and Regulates Hair Cell Subtype Development in the Cochlea. PLoS ONE 2010, 5, e11661. [CrossRef]

208. Mazet, F.; Hutt, J.A.; Milloz, J.; Millard, J.; Graham, A.; Shimeld, S.M. Molecular evidence from Ciona intestinalis for the evolutionary origin of vertebrate sensory placodes. Dev. Biol. 2005, 282, 494-508. [CrossRef]

209. Brozovic, M.; Martin, C.; Dantec, C.; Dauga, D.; Mendez, M.; Simion, P.; Percher, M.; Laporte, B.; Scornavacca, C.; Di Gregorio, A.; et al. ANISEED 2015: A digital framework for the comparative developmental biology of ascidians. Nucleic Acids Res. 2016, 44, D808-D818. [CrossRef]

210. Satou, Y.; Kawashima, T.; Shoguchi, E.; Nakayama, A.; Satoh, N. An Integrated Database of the Ascidian, Ciona ntestinalis: Towards Functional Genomics. Zool. Sci. 2005, 22, 837-843. [CrossRef]

Publisher's Note: MDPI stays neutral with regard to jurisdictional claims in published maps and institutional affiliations.

(C) 2020 by the authors. Licensee MDPI, Basel, Switzerland. This article is an open access article distributed under the terms and conditions of the Creative Commons Attribution (CC BY) license (http://creativecommons.org/licenses/by/4.0/). 